Laboratoire de Recherche en Gestion $\&$ Economie
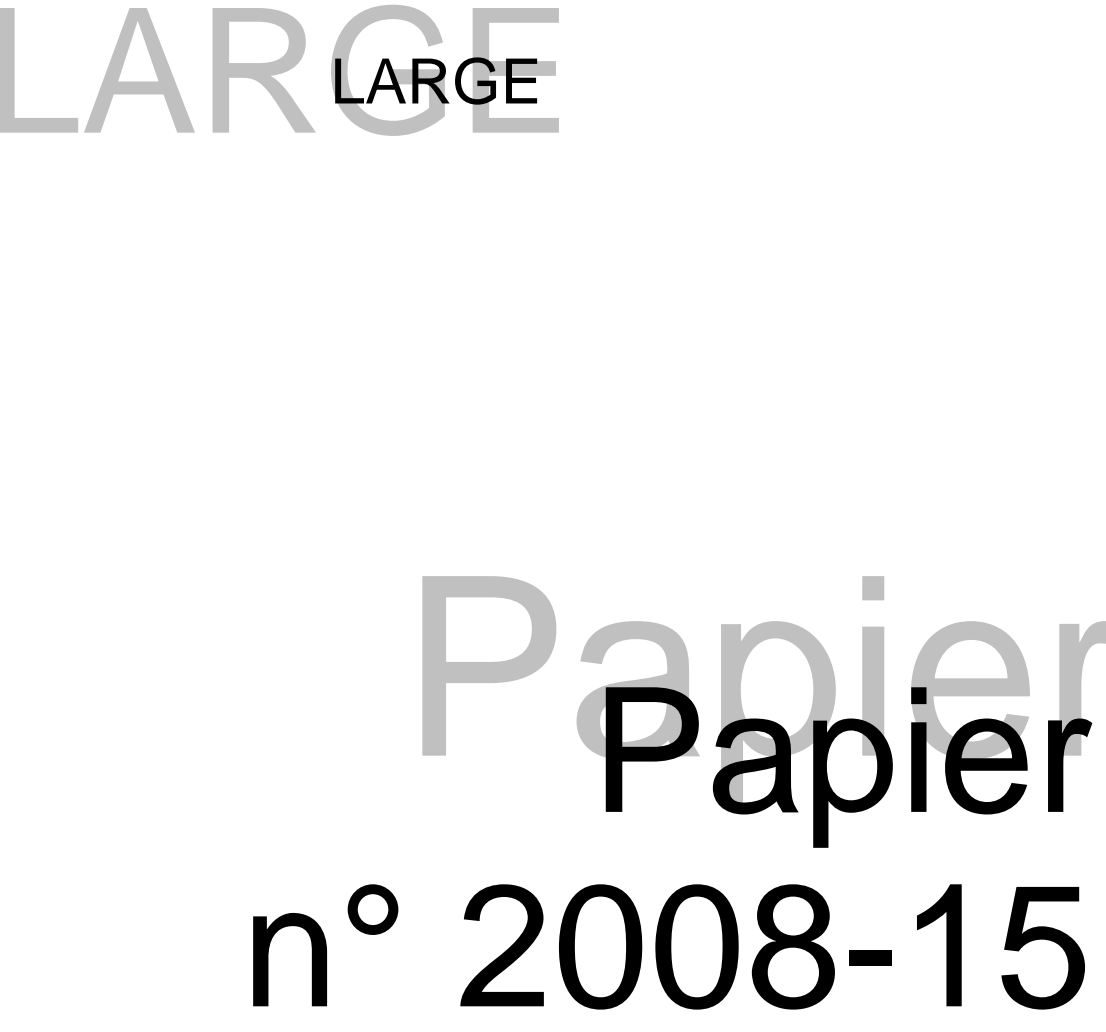

Are private banks more efficient than public banks ? Evidence from Russia

Alexei Karas / Koen Schoors / Laurent Weill

Faculté des

Septembre 2008

sciences économiques

et de gestion

PEGE

61, avenue de la Forêt Noire 67085 STRASBOURG Cedex

Tél. : (33) 0390242152

Fax : (33) 0390242064

www-ulp.u-strasbg.fr/large

Institut d'Etudes Politiques 47, avenue de la Forêt Noire 67082 STRASBOURG Cedex 


\title{
Are private banks more efficient than public banks? Evidence from Russia
}

\author{
Alexei Karas \\ Ghent University \\ Koen Schoors \\ Ghent University \\ Laurent Weill ${ }^{1}$ \\ University of Strasbourg
}

\begin{abstract}
We study whether bank ownership is related to bank efficiency in Russia. We find that foreign banks are more efficient than domestic private banks and - surprisingly - that domestic private banks are not more efficient than domestic public banks. These results are not driven by the choice of the production process, the bank's environment, the management's risk preferences, the bank's activity mix, size or the econometric approach. The evidence in fact suggests that domestic public banks are more efficient than domestic private banks and that the efficiency gap between these two types of banks is not lower after the introduction of deposit insurance in 2004. This may be due to increased switching costs or to the moral hazard effects of deposit insurance. The policy conclusion is that the efficiency of the Russian banking system may benefit more from increased levels of competition and higher access of foreign banks than from bank privatization.
\end{abstract}

JEL classification: G21; P30; P34; P52

Keywords: Bank Efficiency; State Ownership; Foreign ownership; Russia

\footnotetext{
${ }^{1}$ Corresponding author. E-mail: laurent.weill@urs.u-strasbg.fr. Address: Institut d'Etudes Politiques, 47 avenue de la Foret Noire, 67000 Strasbourg, France.
} 


\section{Introduction}

This paper assesses the efficiency of the nascent Russian banking system. The central question we pose is whether bank ownership has any effect on bank efficiency in Russia. We discern foreign-owned banks (foreign banks), privately owned banks (private banks) and state-owned banks (public banks). We find that foreign banks are more efficient than domestic private banks and - surprisingly - that domestic private banks are not more efficient than domestic public banks. These results are not driven by differences in activity mix, risk preferences or bank environment and not explained by the absence of explicit deposit insurance for domestic private banks.

Transition countries appear to be a fertile testing ground for the comparative analysis of public and private banks' efficiency, but first appearances can be deceiving. Indeed, this comparative analysis failed to yield clear answers because in most countries foreign entry and bank privatization went hand in hand. By consequence the empirical results for these countries were largely interpreted in terms of efficiency gaps between foreign and domestic ownership rather than between public and private ownership. In Russia however partial bank privatization was achieved relatively quickly, while foreign bank entry remained at a relatively low level in the first 15 years of transition ${ }^{2}$. Still, partial public ownership in various forms remained a robust characteristic of the Russian banking sector throughout transition. The Central Bank of Russia (CBR) has played an important role through the commercial banks under her direct control, namely Sberbank and Vneshtorgbank. In addition, government bodies of several levels own banks. There are examples of villages, provinces, cities, federal bodies and state firms in this position. For October 2001 for example, we find that the 27 banks that are majority owned by state bodies (out of 1277 banks in total) control 53\% of banking assets and 39\% of banking liabilities. Neglecting the CBR's commercial banking activities through Sberbank and Vneshtorgbank., the remaining 25 public banks hold no less than $6 \%$ of total banking assets and $8 \%$ of total banking liabilities. The Russian banking industry therefore presents us with the exceptional opportunity to disentangle efficiency differences between foreign, public and private banks for a sufficiently large number of banks. This study is therefore a complement to the literature on foreign ownership and efficiency in emerging market economies and its conclusions contribute to our understanding of emerging market economies' banking sectors.

Efficiency comparisons between public and private banks are cumbersome in emerging market economies because both types of banks are subject to different institutional environments, for example the implicit full deposit insurance typically enjoyed by public banks, but not by private banks. Any found differences in the cost effectiveness between

\footnotetext{
${ }^{2}$ The Central Bank of Russia (CBR) repeatedly showed its eagerness to cap foreign entry to the banking sector. The Association of Russian Banks has consistently lobbied the government to limit foreign bank entry using the classic infant industry protection argument. Russia was ultimately forced to commit itself to a gradual opening of its financial market to foreign competition because of its desire to entry the WTO.
} 
private and public banks may therefore be attributable to this difference in deposit insurance, which may render public banks' access to deposits less costly in terms of labor and physical capital. In Russia too, public banks were always covered, albeit implicitly, by deposit insurance, while household deposits held at private banks are covered by deposit insurance only since 2004. To control for this we perform our estimations for two sub-samples, one before (2002) and one after (2006) the introduction of deposit insurance for household deposits at private banks. This allows us to assess whether any found difference in efficiency may be partly attributable to differences in deposit insurance and whether the more level playing field of generalized deposit insurance for household deposits effectively reduces the efficiency difference.

In the following section we overview the bank efficiency literature in connection with our study. Section 3 presents the recent history of the Russian banking sector. This is followed by an overview of the data in section 4 and the estimation methodology in section 5. Section 6 lays out the main results. Section 7 provides further robustness checks by repeating the analysis for a size -matched sample and employing a very different econometric approach. We end with concluding remarks in section 8 .

\section{Related literature}

The empirical literature on privatization in transition countries has found that the method and timing of privatization are related to its performance effects. Frydman et al. (1999) find that privatization has no beneficial effect on performance if firms fall under the sway of insider owners (managers or employees), while the positive performance effect is pronounced if the firm is privatized to outsider owners. Brown et al. (2006) document that foreign privatization has larger productivity effects than domestic privatization in a set of four transition countries.

There is also ample evidence for transition countries that foreign firms are more efficient than domestic firms, be it in the banking sector or in other sectors. Foreign banks may be more efficient than domestic ones because of their more advanced technology, superior management practices, better access to capital or the implicit deposit insurance through the deep pockets of the foreign mother bank.

These economy-wide results are sustained by more detailed banking sector studies that apply stochastic frontier models. Weill (2003) shows in a study of the Czech Republic and Poland that foreign-owned banks are indeed more efficient than domestic-owned banks and that this is driven neither by differences in bank size nor by differences in the structure of activities. Hasan and Marton (2003) find in a Hungarian country-study that foreign banks were more efficient already in the period 1993-1997, early in transition. Fries and Taci (2005) find in a study of 15 East European transition countries (including Russia) that private banks are more cost efficient than state-owned banks. Within the class of private 
banks, they confirm the result of Weill (2003) that privatized banks with majority foreign ownership are the most cost efficient. These are followed by newly established private banks, both domestic and foreign owned, and finally by privatized banks with majority domestic ownership, though these are still more efficient than state-owned banks. Bonin et al. (2005a) analyze the effects of ownership on bank efficiency on a set of eleven transition countries for the period 1996-2000. They apply a stochastic frontier approach to compute bankspecific efficiency scores and relate these to ownership in second-stage regressions. Foreignowned banks are again confirmed to be more cost-efficient, collect more deposits and grant more loans than other banks. The magnitude of increased efficiency from foreign ownership is $6 \%$ or higher. State-owned banks are not appreciably less efficient than de novo domestic private banks, but they are less efficient than those already privatized and, which provides support to the idea that better banks were privatized first. In a companion paper with comparable methodology Bonin et al. (2005b) analyze whether the method and the timing of bank privatization affect bank efficiency. They find that voucher privatization does not lead to increased efficiency and early-privatized banks are more efficient than later-privatized banks.

Kraft, Hofler and Payne (2006) study the Croatian banking system and find that new private and privatized banks are not more efficient than public banks and that privatization does not immediately improve efficiency, while foreign banks are substantially more efficient than all domestic banks.

A number of studies apply data envelopment analysis to examine bank efficiency in Central and Eastern Europe. These include for example Grigorian and Manole (2006), who study 17 European transition countries, Jemric and Vujcic (2002), who look at Croatia, and Havrylchyk (2006), who studies Poland. In accordance with the findings of the stochastic frontier literature, all studies find that foreign banks are more efficient than domestic ones. Grigorian and Manole (2006) find in addition that privatization does not automatically lead to higher efficiency, which is in line with Bonin et al. (2005a). This superior efficiency of foreign banks is however not necessarily found in other emerging market economies. Sensarma (2006) finds for India that foreign banks are less efficient than either public or private domestic banks.

Two studies investigate bank efficiency in Russia. Fries and Taci (2005) study the cost efficiency of banks from 15 post-communist countries including Russia between 1994 and 2001. They apply the one-stage Battese and Coelli (1995)'s stochastic frontier model and find that foreign ownership and private ownership are both associated with greater efficiency. Their findings, however, are based on a cross-country sample and need, therefore, not equally hold for every country. This observation is particularly relevant for Russia given their very limited sample of Russian banks (48 out of more than 1000 existing banks).

Styrin (2005) solves these problems by using a large dataset of Russian banks obtained from the Central Bank of Russia for the period 1999-2002. While efficiency scores are estimated in a first stage with the stochastic frontier approach, they are regressed on a set of 
potential determinants including public ownership and foreign ownership in a second stage. Public ownership is innovatively defined as the actual affiliation with the state measured by the ratio of interest income received from the government to total interest income. This paper concludes in favor of a better efficiency of foreign banks, whereas public ownership is not significant to explain efficiency. The econometric two-stage approach and the exclusion of physical capital from the list of inputs are the paper's major limitations.

We use a similar dataset extended to 2006 and adopt the one-stage approach proposed by Battese and Coelli (1995) to investigate the cost efficiency of Russian banks. Next to solving the limitations of previous studies we contribute to the literature by studying whether the introduction of generalized deposit insurance had any effects on banks' comparative efficiency.

\section{History and problems of the Russian banking sector}

The privatization of Russia's former 'spetsbanki' ${ }^{3}$ was a relatively uncontrolled process that started before 1990 -the official start of bank privatization process- and was largely accomplished by the end of 1991, when the Soviet system collapsed. This secessionist privatization yielded a few large successors (Sberbank, Vneshtorgbank, Mosbiznesbank, Promstroibank and SBS-Agro) and more than 600 relatively small successors. Most of these were reluctant to restructure, as mirrored in higher costs, higher loan rates, poorer loan quality and smaller capital buffers (see Schoors, 2003). Not surprisingly most of the smaller successors faltered in the period 1995-1998. In the aftermath of the August 1998 crisis the larger successors were also swept away, with the notorious exceptions of Sberbank and Vneshtorgbank which survived as daughters of the CBR and now control a considerable part of the Russian banking market ${ }^{4}$. At present, the vast majority of Russian banks are unburdened by lingering Soviet deficiencies: most private banks are de novo banks -the privatized 'spetsbanki' faltered in the period 1992-1999-, while most public banks have been created after the collapse of the Soviet Union by government bodies like state enterprises, cities and federal, regional or local governments (see Tompson, 2004 and Vernikov, 2007). In our sample we count 25 of the latter category. Still, the banking sector has been faced with a number of serious problems throughout its history.

\footnotetext{
${ }^{3}$ In 1987 the Soviet Union turned its monobank system into a kind of two tier banking system with a embryonal central bank (Gosbank) and specialized 'commercial banks'. These were Sberbank (the savings bank), Promstroibank (industry and construction), Zhilsotsbank (housing and communal financing), Agroprombank (Agriculture) and Vneshtorgbank.(foreign trade). These specialized banks are commonly referred to as 'spetsbanki'.

${ }^{4}$ In its 2005 Annual Report, Sberbank claims it holds $54.2 \%$ of total retail deposits, $44.1 \%$ of consumer loans, $32.2 \%$ of corporate loans, $16.6 \%$ of government securities and $26.5 \%$ of total Russian banking assets. The share in ruble-denominate retail deposits is even higher with more than $70 \%$.
} 
Early in transition, banks clearly preferred speculation to lending (Schoors, 2001). Bank lending to the non-financial sector shrank year after year as a share of total banking assets until 1999. In 2003, bank loans to the non- financial sector only amounted to just $17.0 \%$ of GDP and financed as little as $4.8 \%$ of fixed investment. ${ }^{5}$ Since then the situation has improved. This reluctance to lend seems rational with hindsight. The presence of soft legal constraints (Perotti, 2002) rendered the enforcement of overdue claims difficult to impossible. Bank lending was further depressed by huge information asymmetries between banks and their prospective customers, and by the lack of screening and monitoring skills in the banks themselves and the economy at large. Banks were therefore unable to identify good potential borrowers (Brana, Maurel and Sgard, 1999), and often preferred not to lend at all. Moreover, the vast amount of tiny banks and the lack of a transparent information system about credit histories may have contributed to depressing lending (Pyle, 2002).

The largest part of the lending went to connected agents, regardless of the viability of the lending project, and with only very weak monitoring incentives (Laeven, 2001). Many of the newly founded private banks were captured by their owners. Such "pocket banks" operated as treasuries for a firm or a group of firms rather than independent banks. Note that the government, too, is to some extent a connected party, because several banks are captured by local, regional, or national governments. At the start of 2003 , federal or regional authorities held majority stakes in 23 banks, the regional authorities held minority stakes in several more banks and a large number of state enterprises were part-owners of banks (Tompson, 2004).

The average loan quality was negatively affected by the combined problems of connected lending, soft legal constraints, information asymmetries and the lack of screening and monitoring skills. A leaked analysis of Russian banks after the crisis of August 1998 shows that the major cost for banks was not the devaluation loss or the government default on treasury bills, but bad loans hidden and accumulated during the preceding period. ${ }^{6}$ Schoors and Sonin (2005) explain how the Russian banking system was stuck in a passivity trap, where it is rational for each individual bank to hide bad loans rather than collecting them. Economic growth after 2000 allowed Russian banks to 'grow' out of bad loans, but the problem of loan quality is still a latent threat to the Russian banking system.

The Russian banking sector has in the past suffered from poor capitalization, especially considering the poor quality of assets and the large exposure to exchange rate risk. This overexposure was revealed when the devaluation in August 1998 sent capital of many Russian banks from positive to negative overnight (Perotti, 2002). The CBR has steadily tightened capital standards since 1999 and Claeys and Schoors (2007) show that these standards are indeed enforced. As a result capital levels have reached more acceptable levels. Still our data reveal that the average capitalization of the Russian banks is substantially higher

\footnotetext{
${ }^{5}$ Data from the CBR Bulletin of Bank Statistics.

${ }^{6}$ See 'The newly-wed and the nearly dead', Euromoney, June 1999.
} 
than the weighted average capitalization, implying that the capital buffer is lower in the banks that are most important for systemic stability.

The institutional stability of Russian banks has proven weak with systemic problems in 1994, 1995, 1998 and 2004. Since 1992, more than 2000 Russian banks were liquidated or vanished. Sometimes this was due to a combination of the above-mentioned factors (poor capitalization, excessive speculative risk, endemic bad loans, connected lending, etc.), but there were also several cases of Ponzi schemes where crooks cheated depositors and fled with their money. In the aftermath of the August 1998 crisis it became apparent that the soft legal constraints faced by banks encouraged asset stripping and left creditors to bear the brunt of the cost of failure (Perotti, 2002). Claeys and Schoors (2007) give an overview of the CBR's relatively weak prudential supervision and control during the first decade and show that a policy rule-based enforcement of bank standards is difficult for the CBR because of conflicts with systemic stability concerns. Depositors reacted to this widespread institutional instability by either disciplining their banks in a sophisticated way ${ }^{7}$ (Karas, Pyle and Schoors, 2006) or fleeing to the safe heavens of Sberbank and Vneshtorgbank that -like all public banks- were covered by an implicit state guarantee ${ }^{8}$ (see OECD, 2004). Figure 1 shows how Sberbank's share of private deposits ${ }^{9}$ reached a peak of close to 80\% in 1998.

The government wanted to restore some competition in the deposit market and reacted by providing a form of partial deposit insurance. The federal law on deposit insurance was introduced in 2003, but the system became only operational in September $2004^{10}$. Sberbank was initially exempted and kept its full state guarantee until the 1 st of January 2007, when it finally became subject to the new deposit insurance scheme. Other regulatory advantages of Sberbank (for example lower required reserves on ruble deposits) were also abolished. This gradually more level playing field ensured that Sberbank's share of private deposits gradually fell during the last five years to a still very high level of about $50 \%$ in 2006 (see figure 1).

In table 1 we summarize some of the crucial indicators of the recent developments of the Russian banking system. By early 2006 there were 1253 banks, among which only 1045 money deposit banks (covered by the deposit insurance scheme) with 3295 bank branches. More than 30\% of these bank branches were however still operated by Sberbank, such that the average bank had about two branches. Clearly the average Russian bank is tiny when compared to European or world standards. By 2006 the Russian market counted 62 majority

\footnotetext{
${ }^{7}$ By interpreting very high promised deposit rates as a proxy of institutional instability.

${ }^{8}$ Sberbank has a huge branch network and carries a government guarantee. The government lent credibility to this guarantee by supporting Sberbank when needed and using it as a device to absorb deposits from large defunct deposit banks in the aftermath of the 1998 crisis. The same holds for Vneshtorgbank as demonstrated in the mini-crisis in May-July 2004, when Vneshtorgbank acquired Gutabank, one of the larger deposit banks under attack. As a result, Sberbank and Vneshtorgbank continue to dominate a highly concentrated deposit market.

${ }^{9}$ Both ruble- and foreign currency-denominated private deposits.

${ }^{10}$ Although an unrelated and opaque form of state guarantee was already granted to all banks in July 2004 to stop the evolving banking panic.
} 
foreign-owned banks, but their branch network was still relatively underdeveloped. On the other hand banking has clearly revived during the last five years, with bank lending rising from $17 \%$ of GDP in 2001 to 32\% of GDP in 2006 and private deposits rising from $8 \%$ of GDP to $14 \%$ of GDP over the same period. Average interest rates seem still high in nominal terms but are low once inflation is taken into account. Clearly Russian banks are increasingly playing their role as effective intermediaries between savings and investments, but the banking system still suffers from the predominance of tiny banks with underdeveloped branch network, excessive concentration and lack of foreign competition. Although private deposit collection is growing it remains far behind corporate lending.

\section{Data and variables}

The quarterly bank balances and profit and loss accounts were made available to the authors by the financial information agency Interfax ${ }^{11}$. The chosen sample periods (2002 and 2006) are convenient to properly detect longitudinal effects of private ownership. Brown et al (2006) find that positive effects of domestic privatization appear immediately in Hungary, Romania, and Ukraine, but emerge only five years after privatization in Russia. In our study almost all remaining banks are de novo banks and the few remaining privatized banks are considered 10 years or more after privatization, so any positive efficiency effects are expected to have appeared by then.

The panel is unbalanced because some banks fail, some merge, and some are founded during the sample period. If a bank merged or was acquired we treat the resulting larger bank as "new". To identify foreign banks, we use the quarterly lists of 100\% foreign-owned banks provided by the CBR since 1999. The lists of banks with the state as a majority owner are available at two points in time, February 1, 2002 (Matovnikov, 2002) and July 1, 2005 (Mamontov, 2005). These lists reveal that the state ownership category remains stable over our sample period.

We perform estimations before (2002) and after (2006) the introduction of deposit insurance in 2004. For each sub-period, we use a balanced panel which is more convenient for the application of the Battese and Coelli (1995)'s model. As efficiency scores are relative measures of performance, we need to have comparable banks in terms of practiced activities. We therefore only keep banks with both shares of deposits and loans in total assets greater than $10 \%$. Our final sample consists of 747 banks (including 19 public banks and 26 foreign banks) for 2002 and 471 banks (including 15 public banks and 20 foreign banks) for 2006.

The literature disagrees on the role of deposits in the production process of banks. The classical production approach treats deposits and loans as outputs and labor and physical capital as inputs. The intermediation approach first used by Sealey and Lindley (1977) views

${ }^{11}$ Karas and Schoors (2005) provide a detailed description of the dataset and confirm its consistency with other data sources. 
banks as intermediaries between savings and investments in the economy and treats earning assets as outputs and deposits as inputs.

The weak development of financial markets makes a clear focus on the lending and deposit activities of banks relevant for Russia. Therefore we tend to prefer the production approach in this paper. The intermediation approach has the disadvantage that deposits are neglected as an important output. There exists also an argument in favor of the intermediation approach though. Public and foreign banks might have access to cheaper funding if depositors believe those banks to possess additional protection compared to private domestic banks. Public banks have enjoyed the explicit state guarantee backing their retail deposits, which was scrapped only at the end of 2003. In addition their cost of funds is reduced by the perception that the state will stand behind them (Tompson, 2004). Foreign banks' deposits may also enjoy an implicit (by the mother bank) or an explicit deposit guarantee (in some countries clients of foreign branches of domestic banks are covered under the national deposit insurance scheme). Such guarantees, be they perceived or real, could affect input prices for deposits, but this is not considered in the production approach, because the deposit cost is not included in the measure of total costs. This gives a rationale for the use of the intermediation approach, that considers deposits as an input rather than an output and that includes the cost of deposits in the measure of total costs. In robustness checks, we will substitute the intermediation for the production approach. Our results are however robust to the choice of the production process. This is not unexpected given the finding of Wheelock and Wilson (1995) and Berger et al. (1997), that the choice of the approach may have a considerable impact on the level of the efficiency scores but not on their rankings.

For the production approach, the output variables are total deposits and total loans. The input prices are the price of physical capital, measured by the ratio of other operating expenses to fixed assets, and the price of labor, measured by the ratio of personnel expenses to total assets ${ }^{12}$ as data on the number of employees is not available (Altunbas et al. 2000, Weill, 2003). As observed by Maudos et al. (2002), the latter ratio can be interpreted as labor cost per worker (personnel expenses to number of employees) adjusted for differences in labor productivity (number of employees to total assets), since it is the product of these ratios. Total costs are the sum of personnel expenses and other operating expenses. Controls for environment, risk preferences and activities mix include seven geographical district dummies, the log of total assets, the log of equity, the share of bad loans in total loans, and the percentage breakdown of banks' total deposits and loans by counterpart (households, firms, government, banks).

For the intermediation approach, the output variables are total loans and total securities, while the input prices are the deposit rate (measured as the ratio of interest paid on deposits to interest bearing deposits), the price of physical capital (as defined before), and

\footnotetext{
${ }^{12}$ We use the Tukey box-plot to detect outliers: for each input price we drop observations lying out of the range defined by the first and third quartile minus/plus two times the interquartile range.
} 
the price of labor (as defined before). Total costs are the sum of interest paid on deposits, personnel expenses and other operating expenses.

Table 2 compares the means of key variables of private and public banks. Table 3 does the same for domestic and foreign banks. Both public and foreign banks are much bigger, slightly less capitalized and more frequently located in the Moscow area relative to their counterparts, respectively, private and domestic banks. These patterns are more pronounced in the second sub-period. Compared to private banks, public banks grant relatively more loans to companies and banks and relatively less loans to households. Not surprisingly, public banks rely relatively more on the government as a source of funding. Foreign banks are extremely active on the interbank market, both in terms of borrowing and lending, while domestic banks are predominantly occupied with core activities: granting loans to companies and individuals and collecting core deposits. For all bank categories household deposits have become a much more important source of funding over time.

\section{Methodology}

This section develops the methodology adopted to estimate cost efficiency of Russian banks. Cost efficiency measures how close a bank cost is to what a bank optimal cost would be for producing the same bundle of outputs. It then provides information on wastes in the production process and on the optimality of the chosen mix of inputs.

Several techniques have been proposed in the literature to measure efficiency with frontier approaches. While nonparametric approaches, e.g. DEA, use linear programming techniques, parametric approaches, such as stochastic frontier approach or distribution-free approach, apply econometric tools to estimate the efficiency frontier. We adopt stochastic frontier approach in our study, following many studies on banking efficiency in transition countries (Weill, 2003; Bonin et al., 2005a; Fries and Taci, 2005). In comparison to DEA, this approach presents the advantage to disentangle inefficiency from a statistical noise taking exogenous events into account in the residual (the distance from the efficiency frontier). In section 7 we also present DEA estimates as additional robustness checks.

The stochastic frontier approach assumes that total cost deviates from the optimal cost by a random disturbance, $v$, and an inefficiency term, $u$. Thus the cost function is $T C=f(Y$, $P)+\varepsilon$ where $T C$ represents total cost, $Y$ is the vector of outputs, $P$ the vector of input prices and $\varepsilon$ the error term which is the sum of $u$ and $v \cdot u$ is a one-sided component representing cost inefficiencies, meaning the degree of weakness of managerial performance. $v$ is a two-sided component representing random disturbances, reflecting luck or measurement errors. $u$ and $v$ are independently distributed. $u$ is assumed to have a truncated normal distribution, while $v$ is assumed to have a normal distribution. $\sigma v^{2}$ and $\sigma u^{2}$ are the respective variances of $u$ and $v$. According to Jondrow et al. (1982), firm-specific estimates of 
inefficiency terms can be calculated by using the distribution of the inefficiency term conditional on the estimate of the composite error term.

The more straightforward procedure is the so-called "two-stage procedure": the stochastic frontier model is estimated in the first stage, while the obtained efficiency scores are regressed on a set of explanatory variables including ownership variables in the second stage. Although often applied in the literature, this two-stage procedure presents two important econometric problems, as observed by Kumbhakar and Lovell (2000). First, it assumes that the efficiency terms are identically distributed in the estimation of the stochastic frontier model of the first stage, while in the second stage this assumption is contradicted by the fact that the regression of the efficiency terms on the explanatory variables suggests that the efficiency terms are not identically distributed. Second, the explanatory variables must be assumed as uncorrelated with the variables of the cost frontier function, or else the maximum likelihood estimates of the parameters of the cost frontier function would be biased because of the omission of the explanatory variables in the first stage. But then, the estimated efficiency terms that are explained in the second stage are biased estimates, as they are estimated relative to a biased representation of the cost frontier.

Therefore, we choose to use the "one-stage procedure" proposed by Battese and Coelli (1995), which solves these econometric problems. They propose a procedure for panel data, in which the non-negative inefficiency term is assumed to have a truncated distribution with different means for each firm. As a result, the distributions of the inefficiency terms are not the same, but are expressed as functions of explanatory variables. The inefficiency terms are then independently but not identically distributed. They are obtained by truncation at zero of the $\mathrm{N}\left(\mu_{i t}, \sigma u^{2}\right)$ distribution: $\mu_{i t}=q_{i t} \delta$, where $z_{i t}$ is a vector of explanatory variables, and $\delta$ is a vector of parameters to be estimated.

The estimated model consists of the cost frontier function and an equation explaining inefficiency. As is common in the literature on bank efficiency in transition countries (Weill, 2003, Bonin et al., 2005a, Fries and Taci, 2005) we use a standard translog specification of the cost frontier:

$$
\begin{aligned}
\ln \left(\frac{\mathrm{TC}_{\mathrm{i}, \mathrm{t}}}{\mathrm{pk}_{\mathrm{i}, \mathrm{t}}}\right) & =\beta_{0}+\sum_{\mathrm{m}} \alpha_{\mathrm{m}} \ln \mathrm{y}_{\mathrm{m}, \mathrm{i}, \mathrm{t}}+\frac{1}{2} \sum_{\mathrm{m}} \sum_{\mathrm{j}} \alpha_{\mathrm{m}, \mathrm{i}, \mathrm{t}} \ln \mathrm{y}_{\mathrm{m}, \mathrm{i}, \mathrm{t}} \ln \mathrm{y}_{\mathrm{j}, \mathrm{i}, \mathrm{t}}+\beta_{1} \ln \left(\frac{\mathrm{pl}_{\mathrm{i}, \mathrm{t}}}{\mathrm{pk}_{\mathrm{i}, \mathrm{t}}}\right) \\
& +\beta_{2}\left[\ln \left(\frac{\mathrm{pl} \mathrm{i}_{\mathrm{i}, \mathrm{t}}}{\mathrm{pk_{ \textrm {i } , \mathrm { t } }}}\right)\right]^{2}+\sum_{\mathrm{m}} \gamma_{\mathrm{m}} \ln \left(\frac{\mathrm{pl}_{\mathrm{i}, \mathrm{t}}}{\mathrm{pk_{ \textrm {i } , \mathrm { t } }}}\right) \ln \mathrm{y}_{\mathrm{m}, \mathrm{i}, \mathrm{t}}+\varepsilon_{\mathrm{i}, \mathrm{t}}
\end{aligned}
$$

where $T C$ total cost, $y_{m} \mathrm{~m}^{\text {th }}$ bank output $(\mathrm{m}=1,2)$, $p l$ price of labor, $p k$ price of physical capital, $\varepsilon$ the composite error term. Inefficiency is a function of bank-specific variables: 


$$
\mathrm{u}_{\mathrm{it}}=\delta z_{\mathrm{it}}+\mathrm{W}_{\mathrm{it}}
$$

where $u_{i t}$ is the inefficiency, $z_{i t}$ is a $\mathrm{p}^{*} 1$ vector of explanatory variables, $\delta$ is a $1 * \mathrm{p}$ vector of parameters to be estimated, $W_{i t}$ is a random variable defined by the truncation of the normal distribution with mean zero and variance $\sigma^{2}\left(\sigma^{2}=\sigma_{u}{ }^{2}+\sigma_{v}{ }^{2}\right)$. We use the software program Frontier 4.1 to perform the maximum likelihood estimation of the cost frontier.

\section{Results}

We estimate the efficiency model for the period before generalized deposit insurance (2002) and after generalized deposit insurance (2006) to check whether the implementation of the deposit insurance has modified the differences in efficiency between banks with different types of ownership. In all estimations, we include bank ownership variables in the equation explaining inefficiency. Two alternative definitions of public ownership are employed. On the one hand, we include a dummy variable taking the value of one whether the bank is publicly-owned. On the other hand, following Styrin (2005), we measure public ownership by the ratio of interest income received from the government to total interest income. Foreign ownership is taken into account through a dummy variable equal to one whether the bank is foreign-owned.

\section{Insert table 4 around here}

Table 4 describes the main results. While Panel A presents the results when public banks are defined according to the ownership, panel B presents those when public banks are defined according to their activities. In the interpretation, one has to keep in mind that the econometric model identifies inefficiency. Therefore a minus sign indicates that an increase in the explanatory variable implies lower inefficiency, i.e. higher efficiency.

The baseline specification (a) of panel A shows that foreign banks are more efficient than domestic private banks and public banks, and that public banks are more efficient than domestic private banks after the introduction of deposit insurance. Indeed, while the estimates for public ownership are negative and insignificant in specification (a), specification (d) indicates that the efficiency gap between public banks and domestic private banks becomes significant after the introduction of generalized deposit insurance. In an economic sense, the found efficiency differences are considerable. This is also true in panel B where public banks are identified according to their activities rather than their ownership.

In the baseline specifications (a) and (d), we implicitly assume that bank's environment (determined by its location) and risk preferences are management choices. One could however argue that environment is exogenous to management decisions. Consequently, the 
influence of environment should be disentangled to have a satisfactory measure of bank efficiency. In this strand of literature, Dietsch and Lozano-Vivas (2000) have notably shown that environment may explain the cross-country differences in bank efficiency. Furthermore, Hugues and Mester (1993) and Mester (1996) have shown that efficiency differences may also come from differences in managers' risk preferences. Indeed the degree of risk aversion has an impact on cost efficiency. Risk-loving managers may keep the capital down to its cost-minimizing level (the regulatory threshold), while risk-averse managers may prefer to hold higher levels of capital. Consequently, by omitting the level of equity in the cost frontier, we may consider a bank as inefficient while it behaves optimally given the risk preferences of its managers. Berger and Mester (1997) provide an additional reason to include the level of equity into the estimation of the cost efficiency model, based on the fact that the insolvency risk of the bank depends on the equity available to absorb losses. This insolvency risk may lead to higher bank costs ${ }^{13}$. This issue has a particular importance in transition economies like Russia where the insolvency risk of banks is not negligible.

In specifications (b) before generalized deposit insurance and (e) after generalized deposit insurance, we therefore include some environmental variables in the cost frontier. We use information on the district of the bank, taking into consideration the geographical breakdown of Russia in 7 districts. We therefore include 6 dummy variables, which are equal to one whether the bank is located in the concerned district, in the cost frontier. In specifications (c) and (f), we include the logarithm of equity in the estimation of the cost frontier to control for risk preferences in addition to environmental variables, following notably Mester (1996), Altunbas et al. (2000) and Weill (2003). All these specifications show that the baseline results are very robust. Foreign banks remain consistently the most efficient ones and public banks remain consistently more efficient than domestic private ones.

This first set of results suggests that in Russia public banks are more rather than less efficient than domestic private banks. This is in accordance with Styrin (2005) but differs from Fries and Taci (2005). Note however that the latter study obtained results on a crosscountry sample from 15 transition countries including only a very limited sample of Russian banks. In addition, our results surprisingly suggest this efficiency advantage was enhanced rather than reduced by the implementation of the deposit insurance scheme.

Since the results in table 4 do not take into account the possible effect of systematic differences in the deposit rate $^{14}$, table 5 repeats the regressions of table 4 , applying the intermediation approach instead of the production approach. In the intermediation approach the deposit rate is an input cost in the cost function and the total deposit cost is included of the measure of total cost.

\footnotetext{
${ }^{13}$ In our framework, higher solvency risk could affect the costs of the considered cost function through higher labor costs and higher costs of physical capital (to convince depositors to lay out their deposits, banks with lower capital need to invest more in their branch network).

${ }^{14}$ Public banks could have systematically lower deposit rates than private banks.
} 


\section{Insert table 5 around here}

The estimates in table 5 indicate that our unexpected results are very robust to the choice of a production process. Applying the intermediation approach, we again find that foreign banks exhibit superior efficiency, that public banks tend to be more efficient than domestic private banks and that the latter efficiency gap becomes statistically significant after the introduction of deposit insurance. It is suggested therefore that the superior efficiency of public over private banks is not an inheritance of some communist past, but a fact of contemporaneous Russian banking markets.

One explanation for this puzzle could be that public and private banks have different sets of activities and that the typical activity mix of public banks involves fewer costs than the one typically exerted by private banks. In table 6 , we test this idea by including measures of the activity mix in the equation explaining inefficiency.

Include table 6 around here

In each panel of table 6 , we consider the activity mix in the form of lending and deposit shares by type of customer (households, firms, government, bank) and the average loan quality (measured as the ratio of classified loans to total loans). ${ }^{15}$ In panels A and B we apply the production approach, in panels $\mathrm{C}$ and $\mathrm{D}$ the intermediation approach. Panels $\mathrm{A}$ and $\mathrm{C}$ identify public banks through ownership, while panels B and D identify public banks through revealed activities with the government. In each panel we have 4 specifications. In specification (a) we include the regional dummies in the estimation of the efficient frontier and all the activity mix variables in the equation explaining inefficiency. In specification (b) we additionally include equity in the estimation of the efficient frontier. In specification (c) we include the regional dummies and the activity mix variables in the estimation of the efficient frontier, leaving only the loan quality as explanatory variable for the residual inefficiency. In specification (d) we include the regional dummies, equity and the set of activity mix variables in the estimation of the frontier, again leaving only loan quality as explanatory variable for the residual inefficiency. Our three main results are very robust to all these exercises. Foreign banks are again more efficient than domestic private banks. Public banks tend to be more efficient than domestic private ones. This effect seems to be stronger after than before the introduction of deposit insurance. Moreover some results become stronger rather than weaker in some cases. In panel A for example (production approach, public ownership), the public banks superior efficiency now becomes statistically evident even in pre deposit insurance period. In panel C (intermediation approach, public ownership) the public banks become less inefficient than even the foreign banks in the predeposit insurance period.

${ }^{15}$ Since the bank share and the government share are zero for many banks, their sum is the omitted variable for both lending and deposits. The results do not change if households or firms are the excluded category instead. 


\section{Further robustness checks}

The summary statistics in table 2 indicate that public banks are on average very large compared to domestic private banks. If scale economies are present in the Russian banking sector, these considerable size differences may explain our results. Note however that there are also arguments to hypothesize large Russian private banks may be less efficient than their smaller competitors. Claeys and Schoors (2007) find that large Russian banks enjoy regulatory forbearance from the part of the Central bank of Russia. This form of soft legal constraints implies that managers of larger banks are subject to less regulatory pressure. This gives the managers concerned more degrees of freedom to maximize their private benefits of control, which may come at the cost of lower efficiency. To control the effect of size we repeat our estimations for a size matched sample. The matching procedure for the two subperiods runs as follows:

1. We exclude the largest public banks, Sberbank, Vneshtorgbank and Gazprombank from the two samples. They dominate the market and their special status (see above) may drive the results.

2. For each of the remaining public banks, we identify in each time period 20 size-matched (size in terms of total assets) private domestic banks. Specifically, we draw the closest 10 larger and the closest 10 smaller private domestic banks that have not been drawn yet in the specific period. This yields two lists of matching banks, one for the sample before deposit insurance and one for the sample after deposit insurance.

3. Finally we make the sample balanced, by dropping all banks that fail to show up in all 4 quarters of the sub-period.

This procedure yields ultimately 123 matching private domestic banks before deposit insurance (or 492 bank observations) and 141 matching private domestic banks after deposit insurance (or 564 bank observations). All foreign banks are retained in the sample. In annex A.1 we present the summary statistics of this matched sample. One observes that the size differences are now substantially smaller than in the full sample of table 2 .

Insert table 7 around here

In table 7 , we repeat the estimations with all possible controls of panel $A$ in table 6 . In annex A.2 we show the reproduced estimations with the size-matched datasets from the remaining panels of table 6 . Our three main findings are robust but the estimated efficiency gap becomes smaller in most specifications. The public bank variable remains consistently negative in all specifications of all panels although its significance falters in some specifications of the intermediation approach (see Annex A.2). Apparently the observed 
efficiency gap between public and private banks is not only driven by size differences or by the special position enjoyed by the CBR-owned large public banks, but also by some genuine efficiency differences.

As a further robustness check we employed a two-stage DEA procedure. In the first stage we estimate time specific bank efficiency scores for each quarter. We use the quarterly efficiency scores for each bank to compute each bank's mean efficiency scores for each year (2002 before the reform, 2006 after the reform). In a second stage, we regress these mean efficiency scores on a set of determinants (public ownership, foreign ownership, activity) using a Tobit estimator. .This exercise was performed both on the full and the size-matched sample. Results of the second stage Tobit regressions are presented in table 8 . Note that DEA is a totally different estimation strategy, often leading to quite different results. The interpretation of the signs is now different, since DEA measures efficiency rather than inefficiency and since the estimates are time-specific rather than panel estimates.

Insert table 8 around here.

In table 8 we observe that foreign banks are again found to be more efficient than domestic banks. The efficiency of publicly owned banks is never significantly different from that of private banks. The introduction of deposit insurance seems again to be affecting efficiency differences in favor of the foreign banks and the public banks. In the case of publicly owned banks, the signs of the estimates change from insignificantly negative in 2002 to insignificantly positive in 2006.

\section{Concluding remarks}

In the Russian banking market we document three very robust results with respect to bank efficiency. Foreign banks are more efficient than domestic private banks (no surprise), domestic private banks are not more efficient than public banks (surprise) and the introduction of deposit insurance increased any existing efficiency gap between public and private banks (big surprise). These results are not driven by the choice of the production process, environment, risk preferences, activity mix, size or econometric approach.

This result of foreign banks' superior efficiency is in accordance with most literature on this topic in transition countries. Namely, Weill (2003), Fries and Taci (2005) and Bonin et al. (2005a) conclude similarly on samples of banks from various transition countries. This finding is also very robust to the specifications taking environment, equity, size and structure of activities into account. It may find its origin in both reasons proposed by Weill (2003). On the one hand, most shareholders of foreign banks are themselves banks. Consequently these shareholders can provide their know-how in organization and risk analysis to their 
subsidiaries. On the other hand, foreign banks would benefit from better corporate governance as shareholders originating from Western economies would be more used to monitoring bank managers.

But why are private banks not more efficient than public banks in Russia? This unexpected finding is neither in accordance with the general prior that public ownership is less efficient than private ownership, nor with the findings of Bonin et al. (2005a) and Fries and Taci (2005) on cross-country samples of banks from Central and Eastern European countries. Implicit state guarantees may have rendered Russia's public banks' access to deposits less costly in terms of labor and physical capital resulting in higher efficiency. A greater depositor base may in turn lead to a greater pool of loan applicants. Therefore, public banks may also benefit from granting a higher amount of loans than private banks for the same level of costs, because they have to provide fewer efforts to find lenders. But if this explanation is true, the creation of a more level playing field by the introduction of a generalized deposit insurance scheme, no matter how incomplete, should have mitigated the efficiency difference, while we found that the opposite is true. So this explanation must be abandoned. Still deposit insurance may have played a role through moral hazard. There is strong evidence that Russian private domestic banks were subject to strong and sophisticated market discipline before the introduction of deposit insurance (see Karas, Schoors and Pyle, 2006). This forced them in the direction of more efficiency. The introduction of deposit insurance may however have reduced the pressure coming from market discipline, without replacing it with sufficiently strong regulatory pressure. In short, the introduction of deposit insurance may have introduced moral hazard, leading to more rather than less inefficient management practices of private banks.

Alternatively, the observed increase in the efficiency gap between public and private banks may be due to the existence of increased switching costs (see Kim et al., 2003). These switching costs notably derive from costs linked to the time and effort to close an account and open it elsewhere, to become comfortable with unfamiliar procedures and new bank employees, and from costs related to the loss of capitalized value of established relationships. Switching costs may also endogenously result from the fact that banks benefit from better information on their clients than competitors (Sharpe, 1990; Rajan, 1992). The widespread trust in public banks accumulated through their long dominance of the Russian retail markets and the renewed distrust in private banks after the 'mini-crisis' of May-July 2004 (see above) may have increased switching costs from public to private banks. Stronger even, the several weeks of turbulence on the Russian inter-bank market triggered by the CBR's intervention in the case of a bank accused of money-laundering, hampered depositor trust in the banking system and led to the "flight to quality" - the shift of deposits from private to public banks.

Given the fact that Russian public banks are not more inefficient than private ones, the large state presence in the Russian banking sector is not necessarily the cause of its relative inefficiency with the well-known corollaries of lower credit levels and higher financial 
instability. The implication is that bank privatization will not necessarily improve the efficiency of the Russian banking system. Since the main inefficiency seems to reside with domestic private banks, the system's efficiency may benefit more from increased competition than privatization. This can be achieved by creating a more level and more stable regulatory playing field for all banks, an objective the CBR is making progress with, and by opening the market to foreign competition. In this light, the CBR's relentless efforts ${ }^{16}$ of the last years (2006-2007) to get rid of inefficient and fraudulent banks regardless of their size and the increasing access of foreign banks to the Russian banking sector may be more instrumental in boosting the sector's efficiency than yet another round of chaotic privatization.

\footnotetext{
16 These efforts are deeply resented by some of the banks concerned that fear to loose their license and culminated in the brutal murder of the Mr. Kozlov, vice president of the CBR in charge of bank licensing policy in October 2006. The CBR reacted by reinforcing its effort to sweep though the banking licenses.
} 


\section{Reference list}

Altunbas, Y., Evans, L., Molyneux P., Seth, R. (2000). 'Efficiency and Risk in Japanese Banking', Journal of Banking and Finance, 24, pp. 1605-1628.

Battese, G. E. Coelli, T J. (1995). 'A Model for Technical Inefficiency Effects in Stochastic Frontier Production Function for Panel Data', Empirical Economics, 20, pp. 325- 332.

Berger, A., Leusner, J., Mingo, J. (1997). 'The Efficiency of Bank Branches', Journal of Monetary Economics, 40, 1, pp. 141-162.

Berger, A., Mester, L. (1997). 'Inside the Black Box: What Explains Differences in the Efficiencies of Financial Institutions?', Journal of Banking and Finance, 21, pp. 895-947.

Bonin, J. P., Hasan, I., Wachtel, P. (2005a). 'Bank Performance, Efficiency and Ownership in Transition Countries', Journal of Banking and Finance, 29, pp. 31-53.

Bonin, J. P., Hasan, I., Wachtel, P. (2005b). 'Privatization matters: Bank Efficiency in Transition Countries', Journal of Banking and Finance, 29, pp. 2155-2178.

Brana, S., Maurel, M., Sgard, J. (1999). 'Enterprise Adjustment and the Role of Bank Credit in Russia: Evidence from a 420 Firm's Qualitative Survey', Comparative Economic Studies, 41, 4, pp. 47-69.

Brown, J. D., Earle, J.S., Telegdy, I. (2006). 'The Productivity Effects of Privatization: Longitudinal Estimates from Hungary, Romania, Russia and Ukraine', Journal of Political Economy, 114, 1, pp. 61-99.

Claeys, S., Schoors, K. (2007). 'Bank Supervision Russian Style: Evidence of Conflicts between Micro- and Macro-Prudential Concerns', Journal of Comparative Economics, 35, 3, pp. 630-657.

Dietsch, M., Lozano-Vivas, A. (2000). 'How the Environment Determines the Efficiency of Banks, A Comparison between French and Spanish Banking Industry', Journal of Banking and Finance, 24, 6, pp. 985-1004.

Fries, S., Taci, A. (2005). 'Cost Efficiency of Banks in Transition: Evidence from 289 Banks in 15 Post-Communist Countries', Journal of Banking and Finance, 29, pp. 55-81.

Frydman, R., Gray, C., Hessel, M., Rapaczynski, A. (1999). 'When Does Privatization Work? The Impact of Private Ownership on Corporate Performance in the Transition Economies', Quarterly Journal of Economics, 114, 4, pp. 1153-91.

Grigorian D.A., Manole, V. (2006). 'Determinants of Commercial Bank Performance in Transition: An Application of Data Envelopment Analysis', Comparative Economic Studies 48, 3, pp. 497-522.

Hasan, I., Marton K. (2003). 'Development and Efficiency of the Banking Sector in a Transitional Economy: Hungarian Experience', Journal of Banking and Finance, 27, pp. 2249-2271.

Havrylchyk, O. (2006). 'Efficiency of the Polish banking industry: Foreign versus Domestic Banks', Journal of Banking and Finance, 30, pp. 1975-1996. 
Hughes, D.P., Mester L.J. (1993). 'A Quality and Risk-Adjusted Cost Function for Banks: Evidence on the "Too-Big-Too-Fail Doctrine", Journal of Productivity Analysis, 4, pp. 196-315.

Jemric, I., Vujcic, B. (2002). 'Efficiency of Banks in Croatia, A DEA approach', Comparative Economic Studies, 44, pp. 69-193.

Jondrow, J., Lovell, C.A.K., Materov, I., Schmidt, P. (1982). 'On the Estimation of Technical Inefficiency in the Stochastic Frontier Production Function Model', Journal of Econometrics, 19, pp. 233-238.

Karas, A., Pyle, W., Schoors, K. (2006). 'Sophisticated discipline in a nascent deposit market: Evidence from post-communist Russia', BOFIT Discussion Paper 13, Bank of Finland, Helsinki.

Karas, A., Schoors, K. (2005). 'Heracles or Sisyphus? Finding, Cleaning and Reconstructing a Database of Russian Banks', Ghent University Working Paper 05/327.

Kim, M., Kliger, D., Vale, B. (2003). 'Estimating Switching Costs: The Case of Banking', Journal of Financial Intermediation, 12, 1, pp. 25-56.

Kraft, E., Hofler, R., Payne, J. (2006). 'Privatization, Foreign Bank Entry and Bank Efficiency in Croatia: a Fourier-Flexible Function Stochastic Cost Frontier Analysis', Applied Economics, 38, pp. 2075-2088.

Kumbhakar, S., Lovell, C.A.K. (2000). Stochastic Frontier Analysis, Cambridge University Press.

Laeven, L. (2001). 'Insider lending and bank ownership: The case of Russia', Journal of Comparative Economics, 29, pp. 207-229.

Mamontov, A. (2005). 'Gosudarstvo v Bankakh: Zlo ili Blago?', Natsional'nyi Bankovskii Zhurnal 12, 24.

Matovnikov, Mikhail (2002). 'Nadezhnost' Banka Tesno Svyazana so Strukturoi ego Aktsionernogo Kapitala.', Tsentr Ekonomicheskogo Analiza-Interfax, Moscow.

Maudos, J., Pastor, J.M., Perez, F., Quesada, J. (2002). 'Cost and Profit Efficiency in European Banks', Journal of International Financial Markets, Institutions and Money, 12, 1, pp. 33--58.

Mester, L. (1996). 'A Study of Bank Efficiency Taking into Account Risk-Preferences', Journal of Banking and Finance, 20, pp. 1025-1045.

Perotti, E. (2002). 'Lessons from the Russian meltdown: The economics of soft legal constraints', International Finance, 5, pp. 359-399.

Pyle, W. (2002). 'Overbanked and Credit-Starved: A Paradox of the Transition.' Journal of Comparative Economics, 30, pp. 25-50.

Rajan, R. (1992). 'Insiders and Outsiders: The Choice Between Informed and Arm's Length Debt', Journal of Finance, 47, pp. 1367-1400.

Schoors, K. (2001). 'The Credit Squeeze during Russia's Early Transition: A Bank-Based View', Economics of Transition, 9, pp. 205-228. 
Schoors, K. (2003). 'The fate of Russia's former state banks: Chronicle of a restructuring postponed and a crisis foretold', Europe-Asia Studies 55, pp. 75-100.

Schoors, K., Sonin, K. (2005). 'Passive creditors', International Finance 8, pp. 57-86.

Sealey, C.W., Lindley, J.T. (1977). 'Inputs, Outputs and a Theory of Production and Cost at Depository Financial Institutions', Journal of Finance, 32, 4, pp. 1251-1266.

Sensarma, R. (2006). 'Are Foreign Banks Always the Best? Comparison of State-Owned, Private and Foreign banks in India', Economic Modelling 23, pp. 717-735.

Sharpe, S. (1990). 'Asymmetric Information, Bank Lending and Implicit Contracts: A Stylized Model of Customer Relationships', Journal of Finance 45, pp. 1069-1087.

Styrin, K. (2005). 'What Explains Differences in Efficiency Across Russian Banks?', Economics Education and Research Consortium, Russia and CIS, Final report, Moscow.

Tompson, W. (2004). 'Banking reform in Russia: problems and prospects', OECD economics department working papers No. 410, Paris

Vernikov, A. (2007). 'Russia's banking sector transition: Where to?', BOFIT Discussion Papers 5, Bank of Finland, Helsinki.

Weill, L. (2003). 'Banking Efficiency in Transition Economies: The Role of Foreign Ownership', Economics of Transition 11, 3, pp. 569-592.

Wheelock, D., Wilson, P. (1995), 'Evaluating the Efficiency of Commercial Banks: Does Our View of What Banks Do Matter ?', Review of Federal Reserve Bank of Saint-Louis, 77, 4, pp. 39-52. 
Table 1: Some Indicators of recent developments in the Russian banking sector

\begin{tabular}{l|rrrrrr}
\hline Data are at the start of period unless indicated otherwise & \multicolumn{1}{c}{$\mathbf{2 0 0 1}$} & $\mathbf{2 0 0 2}$ & $\mathbf{2 0 0 3}$ & $\mathbf{2 0 0 4}$ & $\mathbf{2 0 0 5}$ & $\mathbf{2 0 0 6}$ \\
\hline Number of credit organizations & 2126 & 2003 & 1828 & 1668 & 1518 & 1409 \\
$\quad$ with banking license & 1311 & 1319 & 1329 & 1329 & 1299 & 1253 \\
$\quad$ license to attract private deposits & 1239 & 1223 & 1202 & 1190 & 1165 & 1045 \\
$\quad$ license to conduct foreign currency operations & 764 & 810 & 839 & 845 & 839 & 827 \\
$\quad$ general license & 244 & 262 & 293 & 310 & 311 & 301 \\
$\quad$ license for operations with precious metals & 163 & 171 & 175 & 181 & 182 & 184 \\
Foreign credit organizations with banking license & 130 & 125 & 126 & 128 & 131 & 136 \\
$\quad$ fully foreign owned & 22 & 23 & 27 & 32 & 33 & 41 \\
$\quad 50$ to 100\% foreign owned & 11 & 12 & 10 & 9 & 9 & 11 \\
Total number of branches & 3793 & 3433 & 3326 & 3219 & 3238 & 3295 \\
$\quad$ of which branches of Sberbank & 1529 & 1233 & 1162 & 1045 & 1011 & 1009 \\
$\quad$ of which branches of fully foreign owned banks & 7 & 9 & 12 & 15 & 16 & 29 \\
Corporate Lending/GDP (eop) & $17 \%$ & $19 \%$ & $22 \%$ & $25 \%$ & $27 \%$ & $32 \%$ \\
Private deposits/GDP & $8 \%$ & $10 \%$ & $11 \%$ & $12 \%$ & $13 \%$ & $14 \%$ \\
Lending/Gross fixed capital formation (eop) & $92 \%$ & $105 \%$ & $120 \%$ & $137 \%$ & $149 \%$ & $177 \%$ \\
Inflation (eop) & $18.6 \%$ & $15.1 \%$ & $12.0 \%$ & $11.7 \%$ & $10.9 \%$ & $9.0 \%$ \\
Deposit rate (period average) & $4.9 \%$ & $5.0 \%$ & $4.5 \%$ & $3.8 \%$ & $4.0 \%$ & $4.1 \%$ \\
Lending rate (period average) & $17.9 \%$ & $15.7 \%$ & $13.0 \%$ & $11.4 \%$ & $10.7 \%$ & $10.5 \%$ \\
\hline
\end{tabular}

Sources: Rosstat, CBR and International Financial Statistics (IMF).

Lending was defined of lending of deposit money banks to private and public enterprises, excluding financial companies. 
Table 2: Means of key variables between private and public banks

\begin{tabular}{|c|c|c|c|c|}
\hline & \multicolumn{2}{|c|}{2002} & \multicolumn{2}{|c|}{2006} \\
\hline & Private banks & Public banks & Private banks & Public banks \\
\hline \multicolumn{5}{|l|}{ Characteristics } \\
\hline Total assets & $1,213.56$ & $17,585.80$ & $2,934.71$ & $160,481.92$ \\
\hline Total costs (production) & 49.26 & 593.51 & 142.65 & $6,575.91$ \\
\hline Total costs (intermediation) & 57.90 & 696.50 & 168.36 & $7,941.45$ \\
\hline Loans & 901.67 & $12,400.59$ & $2,182.47$ & $118,575.98$ \\
\hline Deposits & 855.46 & $9,406.17$ & $2,278.33$ & $127,781.46$ \\
\hline Investment assets & 73.60 & $2,283.15$ & 380.68 & $29,776.67$ \\
\hline Price of labor & 0.0106 & 0.0105 & 0.0102 & 0.0078 \\
\hline Price of physical capital & 1.8113 & 1.5108 & 1.8488 & 2.0085 \\
\hline Price of borrowed funds & 0.0111 & 0.0089 & 0.0121 & 0.0110 \\
\hline Equity/total assets & 0.2726 & 0.2348 & 0.1837 & 0.1297 \\
\hline Bad loans / loans & 0.0184 & 0.0247 & 0.0189 & 0.0114 \\
\hline \multicolumn{5}{|l|}{ Loan activities } \\
\hline Household loans / loans & 0.0790 & 0.0232 & 0.1915 & 0.1474 \\
\hline Firm loans / loans & 0.6649 & 0.6622 & 0.6292 & 0.6654 \\
\hline Government loans / loans & 0.0108 & 0.0104 & 0.0066 & 0.0181 \\
\hline Bank loans / loans & 0.2453 & 0.3042 & 0.1726 & 0.1691 \\
\hline \multicolumn{5}{|l|}{ Deposit activities } \\
\hline Household dep./ deposits & 0.2285 & 0.1267 & 0.4180 & 0.3526 \\
\hline Firm deposits / deposits & 0.6080 & 0.5889 & 0.4796 & 0.3888 \\
\hline Government dep. /deposits & 0.0262 & 0.1298 & 0.017 & 0.1232 \\
\hline Bank dep. / deposits & 0.1373 & 0.1547 & 0.0908 & 0.1355 \\
\hline \multicolumn{5}{|l|}{ Environment } \\
\hline Moscow area & 0.5192 & 0.5789 & 0.3706 & 0.4667 \\
\hline Number of observations & 2912 & 76 & 1824 & 60 \\
\hline
\end{tabular}


Table 3: Means of key variables between domestic and foreign banks

\begin{tabular}{|c|c|c|c|c|}
\hline & \multicolumn{2}{|c|}{2002} & \multicolumn{2}{|c|}{2006} \\
\hline & Domestic banks & Foreign banks & Domestic banks & Foreign banks \\
\hline \multicolumn{5}{|l|}{ Characteristics } \\
\hline Total assets & $1,385.31$ & $8,414.93$ & $7,521.01$ & $17,674.06$ \\
\hline Total cost (production) & 55.35 & 277.95 & 332.89 & 677.80 \\
\hline Total cost (intermediation) & 64.70 & 336.12 & 398.33 & 812.46 \\
\hline Loans & 998.13 & $6,629.65$ & $5,559.31$ & $13,329.95$ \\
\hline Deposits & 860.11 & $6,975.06$ & $5,902.71$ & $14,675.99$ \\
\hline Investment assets & 111.20 & 645.49 & $1,243.35$ & $2,974.54$ \\
\hline Price of labor & 0.0107 & 0.0077 & 0.0103 & 0.0073 \\
\hline Price of physical capital & 1.7828 & 2.3836 & 1.8528 & 1.8800 \\
\hline Price of borrowed funds & 0.0112 & 0.0088 & 0.0122 & 0.0096 \\
\hline Equity/total assets & 0.2725 & 0.2462 & 0.1827 & 0.1677 \\
\hline Bad loans / loans & 0.0184 & 0.0216 & 0.0172 & 0.0508 \\
\hline \multicolumn{5}{|l|}{ Loan activities } \\
\hline Household loans / loans & 0.0792 & 0.0337 & 0.1904 & 0.1838 \\
\hline Firm loans / loans & 0.6718 & 0.4709 & 0.6360 & 0.5036 \\
\hline Government loans / loans & 0.0112 & 0.0001 & 0.0073 & 0.0001 \\
\hline Bank loans / loans & 0.2379 & 0.4954 & 0.1663 & 0.3125 \\
\hline \multicolumn{5}{|l|}{ Deposit activities } \\
\hline Household dep./ deposits & 0.2290 & 0.1401 & 0.4277 & 0.1498 \\
\hline Firm deposits / deposits & 0.6150 & 0.4012 & 0.4809 & 0.3811 \\
\hline Government dep. /deposits & 0.0299 & 0.0001 & 0.0159 & 0.0001 \\
\hline Bank dep. / deposits & 0.1261 & 0.4585 & 0.0755 & 0.4691 \\
\hline \multicolumn{5}{|l|}{ Environment } \\
\hline Moscow area & 0.5118 & 0.7692 & 0.3503 & 0.9000 \\
\hline Number of observations & 2884 & 104 & 1804 & 80 \\
\hline
\end{tabular}

Table 4: The inefficiency of public banks according to the production approach

Panel A: Public banks defined as state-owned banks 


\begin{tabular}{|c|c|c|c|c|c|c|}
\hline \multirow[b]{2}{*}{$\begin{array}{l}\text { Frontier } \\
\text { characteristics }\end{array}$} & \multicolumn{3}{|c|}{ Before generalised deposit insurance (2002) } & \multicolumn{3}{|c|}{ After generalised deposit insurance (2006) } \\
\hline & $\begin{array}{c}\text { (a) } \\
\text { Baseline }\end{array}$ & $\begin{array}{c}\text { (b) } \\
\text { environment }\end{array}$ & $\begin{array}{c}\text { (c) } \\
\text { Equity and } \\
\text { environment }\end{array}$ & $\begin{array}{c}(d) \\
\text { Baseline }\end{array}$ & $\begin{array}{c}\text { (e) } \\
\text { environment }\end{array}$ & $\begin{array}{c}(f) \\
\text { Equity and } \\
\text { environment }\end{array}$ \\
\hline Intercept & Yes & Yes & Yes & Yes & Yes & Yes \\
\hline Public banks & -2.321 & -2.346 & -2.226 & $-2.915^{* * *}$ & $-3.527 * * *$ & $-1.924 * * *$ \\
\hline & $\begin{array}{l}(1.37) \\
2302 *\end{array}$ & $(1.38)$ & $(1.24)$ & $\begin{array}{l}(4.19) \\
(325 * * *\end{array}$ & $\begin{array}{l}(4.34) \\
(504 * * *\end{array}$ & $\begin{array}{l}(4.04) \\
788 * * *\end{array}$ \\
\hline Foreign banks & $\begin{array}{c}-2.393^{*} \\
(1.95)\end{array}$ & $\begin{array}{c}-2.544 \text { (2.67) } \\
(2.67)\end{array}$ & $\begin{array}{l}-2.300 \\
(1.34)\end{array}$ & $\begin{array}{c}-0.325^{2} \\
(3.88)\end{array}$ & $\begin{array}{c}-0.594 \\
(4.00)\end{array}$ & $\begin{array}{c}-4 . / 88^{* x+4} \\
(3.35)\end{array}$ \\
\hline Log-likelihood & -2203.909 & -2192.782 & -2189.672 & -1278.612 & -1270.417 & -1200.630 \\
\hline \multicolumn{7}{|c|}{ Panel B: Public banks defined as banks that receive a high share of interest income from the government bodies } \\
\hline Intercept & Yes & Yes & Yes & Yes & Yes & Yes \\
\hline Public banks & -2.125 & -2.357 & -2.172 & $-3.398 * * *$ & $-3.633^{* * *}$ & $-2.903 * * *$ \\
\hline 1 Hitic Dantiks & $(0.88)$ & (1.01) & $(0.84)$ & (4.35) & $(3.70)$ & (4.66) \\
\hline Foreion banks & $-2.370 * *$ & $-2.535^{* * *}$ & -2.550 & $-6.519^{* * *}$ & $-6.739 * * *$ & $-4.965^{* * *}$ \\
\hline I OICAgII Dal1Ks & $(1.97)$ & $(2.80)$ & $(1.54)$ & $(3.31)$ & $(3.30)$ & $(2.95)$ \\
\hline $\begin{array}{l}\text { Log- } \\
\text { likelihood }\end{array}$ & -2205.207 & -2194.002 & -2190.745 & -1282.249 & -1274.881 & -1202.208 \\
\hline
\end{tabular}

'Environment' means that regional dummies are included in the estimation of the cost frontier. 'Equity' refers to the inclusion of the bank's equity in the estimation of the cost frontier. $\mathrm{N}=2988$ for the first period, $\mathrm{N}=1884$ for the second period. Absolute t-statistics are displayed in parentheses, *, **, *** denote an estimate significantly different from zero at the $10 \%, 5 \%$ or $1 \%$ level. 
Table 5: The inefficiency of public banks according to the intermediation approach

\begin{tabular}{|c|c|c|c|c|c|c|}
\hline \multicolumn{7}{|c|}{ Panel C: Public banks defined as state-owned banks } \\
\hline \multirow[b]{2}{*}{$\begin{array}{l}\text { Frontier } \\
\text { characteristics }\end{array}$} & \multicolumn{3}{|c|}{ Before generalised deposit insurance (2002) } & \multicolumn{3}{|c|}{ After generalised deposit insurance (2006) } \\
\hline & $\begin{array}{c}\text { (a) } \\
\text { Baseline }\end{array}$ & $\begin{array}{c}\text { (b) } \\
\text { environment }\end{array}$ & $\begin{array}{c}\text { (c) } \\
\text { Equity and } \\
\text { environment }\end{array}$ & $\begin{array}{c}\text { (d) } \\
\text { Baseline }\end{array}$ & $\begin{array}{c}\text { (e) } \\
\text { environment }\end{array}$ & $\begin{array}{c}(f) \\
\text { Equity and } \\
\text { environment }\end{array}$ \\
\hline Intercept & Yes & Yes & Yes & Yes & Yes & Yes \\
\hline D $1 . \quad 1$ & -3.018 & -2.801 & -2.507 & $-2.886 * * *$ & $-3.268 * * *$ & $-1.994 * * *$ \\
\hline Public banks & $(1.60)$ & $(1.58)$ & $(1.35)$ & $(4.01)$ & $(2.90)$ & $(4.10)$ \\
\hline & $-1.290 * *$ & $-1.187 *$ & $-1.084^{* *}$ & $-7.020 * * *$ & $-7.162^{* * *}$ & $-5.862^{* * *}$ \\
\hline Foreign banks & $(2.08)$ & $(1.66)$ & $(2.41)$ & $(3.63)$ & $(2.66)$ & $(3.82)$ \\
\hline Log-likelihood & -1983.526 & -1972.305 & -1968.205 & -1040.960 & -1035.344 & -1015.842 \\
\hline \multicolumn{7}{|c|}{ Panel D: Public banks defined as banks that receive a high share of interest income from the government bodies } \\
\hline Intercept & Yes & Yes & Yes & Yes & Yes & Yes \\
\hline Public banks & -0.776 & -1.387 & -1.134 & $-3.888^{* * *}$ & $-4.243^{* * *}$ & $-2.968 * * *$ \\
\hline Public banks & $(0.53)$ & $(0.85)$ & $(0.74)$ & (3.54) & $(3.80)$ & $(4.52)$ \\
\hline Eoreion benles & -1.141 & -1.071 & -0.976 & $-7.093 * * *$ & $-7.240 * * *$ & $-5.943 * * *$ \\
\hline Fore1gn banks & $(1.17)$ & $(1.13)$ & $(1.58)$ & $(3.02)$ & $(3.37)$ & (4.21) \\
\hline $\begin{array}{l}\text { Log- } \\
\text { likelihood }\end{array}$ & -1986.681 & -1975.090 & -1970.917 & -1042.721 & -1037.439 & -1016.970 \\
\hline
\end{tabular}

'Environment' means that regional dummies are included in the estimation of the cost frontier. 'Equity' refers to the inclusion of the bank's equity in the estimation of the cost frontier. $\mathrm{N}=2988$ for the first period, $\mathrm{N}=1884$ for the second period. Absolute t-statistics are displayed in parentheses, *, **, *** denote an estimate significantly different from zero at the $10 \%, 5 \%$ or $1 \%$ level. 
Table 6. Robustness to differences in activity mix

Panel A: Public banks defined as state-owned bank/production approach

\begin{tabular}{|c|c|c|c|c|}
\hline \multicolumn{5}{|c|}{ Pre generalised deposit insurance (2002) } \\
\hline $\begin{array}{l}\text { Frontier } \\
\text { characteristics }\end{array}$ & $\begin{array}{c}\text { (a) } \\
\text { environmen } \\
t\end{array}$ & $\begin{array}{c}\text { (b) } \\
\text { equity } \\
\text { and } \\
\text { environment }\end{array}$ & $\begin{array}{c}\text { (c) } \\
\text { environment } \\
\text { and } \\
\text { activities }\end{array}$ & $\begin{array}{c}\text { (d) } \\
\text { equity } \\
\text { and } \\
\text { environment } \\
\text { and activities }\end{array}$ \\
\hline Intercept & Yes & Yes & Yes & Yes \\
\hline Public banks & $\begin{array}{c}-1.041^{* *} \\
(2.04)\end{array}$ & $\begin{array}{c}-1.153^{* * *} \\
(3.06)\end{array}$ & $\begin{array}{c}-0.679 * * \\
(2.03)\end{array}$ & $\begin{array}{c}-0.801 * * \\
(2.23)\end{array}$ \\
\hline Foreign banks & $\begin{array}{c}-0.803^{* * *} \\
(2.85)\end{array}$ & $\begin{array}{c}-0.873^{* * *} \\
(2.61)\end{array}$ & $\begin{array}{c}-0.584^{* *} \\
(2.06)\end{array}$ & $\begin{array}{l}-0.653 \\
(1.58)\end{array}$ \\
\hline Household deposits $\%$ & Yes & Yes & - & - \\
\hline Firm deposits \% & Yes & Yes & - & - \\
\hline Household loans \% & Yes & Yes & - & - \\
\hline Firm loans \% & Yes & Yes & - & - \\
\hline Bad loans \% & Yes & Yes & Yes & Yes \\
\hline Log-likelihood & -2163.004 & -2162.106 & -2130.126 & -2128.461 \\
\hline \multicolumn{5}{|c|}{ Post generalized deposit insurance (2006) } \\
\hline Intercept & Yes & Yes & Yes & Yes \\
\hline Public banks & $\begin{array}{c}-2.699 * * * \\
(3.85)\end{array}$ & $\begin{array}{c}-1.739 * * * \\
(3.67)\end{array}$ & $\begin{array}{c}-5.397 * * \\
(2.47)\end{array}$ & $\begin{array}{c}-2.859 * * * \\
(3.46)\end{array}$ \\
\hline Foreign banks & $\begin{array}{c}-4.514 * * * \\
(3.71)\end{array}$ & $\begin{array}{c}-3.885^{* * *} \\
(3.64)\end{array}$ & $\begin{array}{c}-7.153^{*} \\
(1.97)\end{array}$ & $\begin{array}{c}-5.523^{* * *} \\
(3.28)\end{array}$ \\
\hline Household deposits $\%$ & Yes & Yes & - & - \\
\hline Firm deposits $\%$ & Yes & Yes & - & - \\
\hline Household loans \% & Yes & Yes & - & - \\
\hline Firm loans \% & Yes & Yes & - & - \\
\hline Bad loans \% & Yes & Yes & Yes & Yes \\
\hline Log-likelihood & $-1226 ; 456$ & -1165.323 & -1230.926 & -1143.223 \\
\hline
\end{tabular}


Panel B: Public banks defined as banks that receive a high share of interest income from the government bodies/ production approach

\begin{tabular}{|c|c|c|c|c|}
\hline \multicolumn{5}{|c|}{ Pre generalised deposit insurance (2002) } \\
\hline $\begin{array}{l}\text { Frontier } \\
\text { characteristics }\end{array}$ & $\begin{array}{c}\text { (a) } \\
\text { environmen } \\
t\end{array}$ & $\begin{array}{c}\text { (b) } \\
\text { equity } \\
\text { and } \\
\text { environment }\end{array}$ & $\begin{array}{c}\text { (c) } \\
\text { environment } \\
\text { and } \\
\text { activities }\end{array}$ & $\begin{array}{c}\text { (d) } \\
\text { equity } \\
\text { and } \\
\text { environment } \\
\text { and activities }\end{array}$ \\
\hline Intercept & Yes & Yes & Yes & Yes \\
\hline Public banks & $\begin{array}{l}-1.348 \\
(1.24)\end{array}$ & $\begin{array}{l}-1.561 \\
(1.58)\end{array}$ & $\begin{array}{l}-0.862 \\
(0.95)\end{array}$ & $\begin{array}{l}-1.137 \\
(1.53)\end{array}$ \\
\hline Foreign banks & $\begin{array}{c}-0.788^{* * * *} \\
(2.89)\end{array}$ & $\begin{array}{c}-0.863^{* *} \\
(2.52)\end{array}$ & $\begin{array}{c}-0.574 * * \\
(2.05)\end{array}$ & $\begin{array}{c}-0.654^{*} \\
(1.70)\end{array}$ \\
\hline Household deposits $\%$ & Yes & Yes & - & - \\
\hline Firm deposits $\%$ & Yes & Yes & - & - \\
\hline Household loans \% & Yes & Yes & - & - \\
\hline Firm loans \% & Yes & Yes & - & - \\
\hline Bad loans $\%$ & Yes & Yes & Yes & Yes \\
\hline Log-likelihood & -2163.432 & -2162.537 & -2130.490 & -2128.775 \\
\hline \multicolumn{5}{|c|}{ Panel B Post generalized deposit insurance (2006) } \\
\hline Intercept & Yes & Yes & Yes & Yes \\
\hline Public banks & $\begin{array}{c}-3.329 * * * \\
(3.37)\end{array}$ & $\begin{array}{c}-2.766^{* * *} \\
(3.87)\end{array}$ & $\begin{array}{l}-3.602 \\
(1.18)\end{array}$ & $\begin{array}{c}-2.855^{* * *} \\
(3.17)\end{array}$ \\
\hline Foreign banks & $\begin{array}{c}-4.553 * * * \\
(3.35)\end{array}$ & $\begin{array}{c}-4.001 * * * \\
(3.63)\end{array}$ & $\begin{array}{l}-5.611 \\
(1.39)\end{array}$ & $\begin{array}{c}-5.627^{* *} \\
(2.43)\end{array}$ \\
\hline Household deposits \% & Yes & Yes & - & - \\
\hline Firm deposits $\%$ & Yes & Yes & - & - \\
\hline Household loans \% & Yes & Yes & - & - \\
\hline Firm loans \% & Yes & Yes & - & - \\
\hline Bad loans \% & Yes & Yes & Yes & Yes \\
\hline Log-likelihood & -1231.047 & -1167.378 & -1235.123 & -1145.789 \\
\hline
\end{tabular}


Panel C: Public banks defined as state-owned banks / intermediation approach

\begin{tabular}{|c|c|c|c|c|}
\hline \multicolumn{5}{|c|}{ Pre generalised deposit insurance (2002) } \\
\hline $\begin{array}{l}\text { Frontier } \\
\text { characteristics }\end{array}$ & $\begin{array}{c}\text { (a) } \\
\text { environmen } \\
t\end{array}$ & $\begin{array}{c}\text { (b) } \\
\text { equity } \\
\text { and } \\
\text { environment }\end{array}$ & $\begin{array}{c}\text { (c) } \\
\text { environment } \\
\text { and } \\
\text { activities }\end{array}$ & $\begin{array}{c}\text { (d) } \\
\text { equity } \\
\text { and } \\
\text { environment } \\
\text { and activities }\end{array}$ \\
\hline Intercept & Yes & Yes & Yes & Yes \\
\hline Public banks & $\begin{array}{c}-1.285^{* * *} \\
(2.31)\end{array}$ & $\begin{array}{c}-1.259 * * \\
(2.36)\end{array}$ & $\begin{array}{l}-1.471 \\
(1.58)\end{array}$ & $\begin{array}{c}-1.447 * \\
(1.93)\end{array}$ \\
\hline Foreign banks & $\begin{array}{l}0.005 \\
(0.02)\end{array}$ & $\begin{array}{l}0.018 \\
(0.11)\end{array}$ & $\begin{array}{c}-1.609 \\
(0.51)\end{array}$ & $\begin{array}{l}-0.155 \\
(0.81)\end{array}$ \\
\hline Household deposits $\%$ & Yes & Yes & - & - \\
\hline Firm deposits \% & Yes & Yes & - & - \\
\hline Household loans \% & Yes & Yes & - & - \\
\hline Firm loans \% & Yes & Yes & - & - \\
\hline Bad loans \% & Yes & Yes & Yes & Yes \\
\hline Log-likelihood & -1917.841 & -1916.956 & -1917.810 & -1917.737 \\
\hline \multicolumn{5}{|c|}{ Post generalized deposit insurance (2006) } \\
\hline Intercept & Yes & Yes & Yes & Yes \\
\hline Public banks & $\begin{array}{c}-1.957 * * * \\
(2.57)\end{array}$ & $\begin{array}{c}-1.857^{* * *} \\
(5.08)\end{array}$ & $\begin{array}{l}-2.244 \\
(1.60)\end{array}$ & $\begin{array}{c}-2.326^{* * *} \\
(3.88)\end{array}$ \\
\hline Foreign banks & $\begin{array}{c}-3.863 * * * \\
(2.93)\end{array}$ & $\begin{array}{c}-4.378^{* * * *} \\
(10.40)\end{array}$ & $\begin{array}{c}-3.924 * * \\
(2.07)\end{array}$ & $\begin{array}{c}-6.275^{* * * *} \\
(3.14)\end{array}$ \\
\hline Household deposits $\%$ & Yes & Yes & - & - \\
\hline Firm deposits \% & Yes & Yes & - & - \\
\hline Household loans \% & Yes & Yes & - & - \\
\hline Firm loans \% & Yes & Yes & - & - \\
\hline Bad loans \% & Yes & Yes & Yes & Yes \\
\hline Log-likelihood & -951.341 & -932.902 & -998.824 & -975.377 \\
\hline
\end{tabular}


Panel D: Public banks defined as banks that receive a high share of interest income from the government bodies / intermediation approach

\begin{tabular}{|c|c|c|c|c|}
\hline \multicolumn{5}{|c|}{ Pre generalised deposit insurance (2002) } \\
\hline $\begin{array}{l}\text { Frontier } \\
\text { characteristics }\end{array}$ & $\begin{array}{c}\text { (a) } \\
\text { environmen } \\
t\end{array}$ & $\begin{array}{c}\text { (b) } \\
\text { equity } \\
\text { and } \\
\text { environment }\end{array}$ & $\begin{array}{c}\text { (c) } \\
\text { environment } \\
\text { and } \\
\text { activities }\end{array}$ & $\begin{array}{c}\text { (d) } \\
\text { equity } \\
\text { and } \\
\text { environment } \\
\text { and activities }\end{array}$ \\
\hline Intercept & Yes & Yes & Yes & Yes \\
\hline Public banks & -0.967 & -0.890 & -1.320 & -1.267 \\
\hline & $(1.53)$ & $(1.47)$ & $(1.10)$ & $(1.17)$ \\
\hline Foreign banks & 0.054 & 0.067 & -0.125 & -0.118 \\
\hline & $(0.24)$ & $(0.38)$ & $(0.53)$ & $(0.59)$ \\
\hline Household deposits $\%$ & Yes & Yes & - & - \\
\hline Firm deposits $\%$ & Yes & Yes & - & - \\
\hline Household loans \% & Yes & Yes & - & - \\
\hline Firm loans \% & Yes & Yes & - & - \\
\hline Bad loans $\%$ & Yes & Yes & Yes & Yes \\
\hline Log-likelihood & -1919.707 & -1918.822 & -1919.208 & -1919.153 \\
\hline \multicolumn{5}{|c|}{ Panel B Post generalized deposit insurance (2006) } \\
\hline Intercept & Yes & Yes & Yes & Yes \\
\hline Public banks & $\begin{array}{c}-2.670^{* *} \\
(2.28)\end{array}$ & $\begin{array}{c}-2.824 * * * \\
(3.98)\end{array}$ & $\begin{array}{l}-2.518 \\
(1.36)\end{array}$ & $\begin{array}{c}-2.978^{* * *} \\
(2.81)\end{array}$ \\
\hline Foreign banks & $\begin{array}{c}-3.892^{* * *} \\
(2.77)\end{array}$ & $\begin{array}{c}-4.359 * * * \\
(3.85)\end{array}$ & $\begin{array}{c}-3.847 * * * \\
(2.76)\end{array}$ & $\begin{array}{c}-6.380^{* * *} \\
(2.76)\end{array}$ \\
\hline Household deposits \% & Yes & Yes & - & - \\
\hline Firm deposits $\%$ & Yes & Yes & - & - \\
\hline Household loans \% & Yes & Yes & - & - \\
\hline Firm loans \% & Yes & Yes & - & - \\
\hline Bad loans \% & Yes & Yes & Yes & Yes \\
\hline Log-likelihood & -953.868 & -934.310 & -1000.718 & -976.560 \\
\hline
\end{tabular}


Table 7: Size matched results

Panel A: Public banks defined as state-owned banks / poduction approach

\begin{tabular}{|c|c|c|c|c|}
\hline \multicolumn{5}{|c|}{ Pre generalised deposit insurance (2002) } \\
\hline $\begin{array}{l}\text { Frontier } \\
\text { characteristics }\end{array}$ & $\begin{array}{c}\text { (a) } \\
\text { environmen } \\
t\end{array}$ & $\begin{array}{c}\text { (b) } \\
\text { equity } \\
\text { and } \\
\text { environment }\end{array}$ & $\begin{array}{c}\text { (c) } \\
\text { environment } \\
\text { and } \\
\text { activities }\end{array}$ & $\begin{array}{c}\text { (d) } \\
\text { equity } \\
\text { and } \\
\text { environment } \\
\text { and activities }\end{array}$ \\
\hline Intercept & Yes & Yes & Yes & Yes \\
\hline Public banks & $\begin{array}{l}-2.130 \\
(1.14)\end{array}$ & $\begin{array}{c}-2.153 * * * \\
(2.73)\end{array}$ & $\begin{array}{c}-0.226 \\
(0.66)\end{array}$ & $\begin{array}{c}-0.244 \\
(0.57)\end{array}$ \\
\hline Foreign banks & $\begin{array}{l}0.412 \\
(0.64)\end{array}$ & $\begin{array}{l}0.384 \\
(1.32)\end{array}$ & $\begin{array}{l}0.039 \\
(0.11)\end{array}$ & $\begin{array}{l}0.012 \\
(0.04)\end{array}$ \\
\hline Household deposits \% & $\begin{array}{l}1.594 \\
(0.71)\end{array}$ & $\begin{array}{l}1.035 \\
(1.46)\end{array}$ & - & - \\
\hline Firm deposits $\%$ & $\begin{array}{l}6.439 \\
(1.23)\end{array}$ & $\begin{array}{c}6.175^{* * * *} \\
(3.26)\end{array}$ & - & - \\
\hline Household loans \% & $\begin{array}{l}2.130 \\
(1.17)\end{array}$ & $\begin{array}{l}2.681 * \\
(1.92)\end{array}$ & - & - \\
\hline Firm loans $\%$ & $\begin{array}{l}2.226 \\
(1.36)\end{array}$ & $\begin{array}{l}2.639 * * \\
(2.23)\end{array}$ & - & - \\
\hline Bad loans \% & $\begin{array}{l}11.841 \\
(1.47)\end{array}$ & $\begin{array}{c}15.918^{* *} \\
(2.53)\end{array}$ & $\begin{array}{l}6.168 \\
(1.62)\end{array}$ & $\begin{array}{l}6.742 \\
(1.22)\end{array}$ \\
\hline Log-likelihood & -397.439 & -397.026 & -390.969 & -390.955 \\
\hline \multicolumn{5}{|c|}{ Post generalised deposit insurance (2006) } \\
\hline Intercept & Yes & Yes & Yes & Yes \\
\hline Public banks & $\begin{array}{l}-0.331^{*} \\
(1.95)\end{array}$ & $\begin{array}{c}-0.190 * * \\
(1.96)\end{array}$ & $\begin{array}{c}-1.406 * * \\
(2.06)\end{array}$ & $\begin{array}{c}-1.280 * * \\
(2.27)\end{array}$ \\
\hline Foreign banks & $\begin{array}{c}-1.433 * * * \\
(6.74)\end{array}$ & $\begin{array}{c}-0.907 * * * \\
(11.58)\end{array}$ & $\begin{array}{c}-2.660^{*} \\
(1.94)\end{array}$ & $\begin{array}{c}-1.987^{* *} \\
(2.36)\end{array}$ \\
\hline Household deposits $\%$ & $\begin{array}{c}-0.815^{* * *} \\
(3.60)\end{array}$ & $\begin{array}{l}0.030 \\
(0.36)\end{array}$ & - & - \\
\hline Firm deposits \% & $\begin{array}{l}-0.222 \\
(1.16)\end{array}$ & $\begin{array}{l}0.154 * * \\
(2.48)\end{array}$ & - & - \\
\hline Household loans \% & $\begin{array}{c}0.718^{* * * *} \\
(2.69)\end{array}$ & $\begin{array}{l}0.293 \\
(1.64)\end{array}$ & - & - \\
\hline Firm loans \% & $\begin{array}{c}0.813 * * * \\
(3.57)\end{array}$ & $\begin{array}{c}0.416^{* * * *} \\
(3.69)\end{array}$ & - & - \\
\hline Bad loans \% & $\begin{array}{l}0.018 \\
(0.03) \\
\end{array}$ & $\begin{array}{l}0.207 \\
(1.08) \\
\end{array}$ & $\begin{array}{l}-3.215 \\
(0.89)\end{array}$ & $\begin{array}{c}-4.126 \\
(1.06) \\
\end{array}$ \\
\hline Log-likelihood & -360.661 & -332.218 & -349.916 & -339.517 \\
\hline
\end{tabular}


Table 8: Robustness to other econometric techniques: DEA

\begin{tabular}{|c|c|c|c|c|c|c|}
\hline \multicolumn{7}{|c|}{ Panel A: Public banks defined as state-owned banks, full sample } \\
\hline \multirow[b]{2}{*}{$\begin{array}{l}\text { Frontier } \\
\text { characteristics }\end{array}$} & \multicolumn{3}{|c|}{ Before generalised deposit insurance (2002) } & \multicolumn{3}{|c|}{ After generalised deposit insurance (2006) } \\
\hline & (a) & (b) & (c) & (d) & (e) & (f) \\
\hline Intercept & Yes & Yes & Yes & Yes & Yes & Yes \\
\hline & -0.007 & -0.0233 & -0.021 & 0.014 & 0.013 & 0.013 \\
\hline Public banks & $(0.32)$ & $(1.16)$ & $(1.07)$ & $(0.68)$ & $(0.63)$ & $(0.61)$ \\
\hline Eoreion bonles & $0.055^{* * *}$ & 0.008 & 0.008 & $0.145^{* * *}$ & $0.135^{* * *}$ & $0.135^{* * *}$ \\
\hline Foreign Danks & $(3.03)$ & $(0.44)$ & $(0.45)$ & $(8.00)$ & $(6.66)$ & $(6.67)$ \\
\hline Activities & - & Yes & Yes & - & Yes & Yes \\
\hline Bad loans & - & - & Yes & - & - & Yes \\
\hline Log-likelihood & 733.983 & 776.945 & 785.229 & 525.603 & 538.238 & 538.296 \\
\hline \multicolumn{7}{|c|}{ Panel B: Public banks defined as state-owned banks, size-matched sample } \\
\hline Intercept & Yes & Yes & Yes & Yes & Yes & Yes \\
\hline Public honlsc & -0.023 & -0.034 & -0.033 & 0.024 & 0.018 & 0.017 \\
\hline Public banks & $(0.68)$ & $(1.01)$ & $(1.00)$ & $(0.78)$ & $(0.63)$ & $(0.60)$ \\
\hline Eomion bo & $0.055^{*}$ & 0.005 & 0.004 & $0.152^{* * *}$ & $0.128^{* * *}$ & $0.112^{* * *}$ \\
\hline Foreign banks & $(1.90)$ & $(0.18)$ & $(0.12)$ & $(6.11)$ & $(4.31)$ & $(3.70)$ \\
\hline Activities & - & Yes & Yes & - & Yes & Yes \\
\hline Bad loans & - & - & Yes & - & - & Yes \\
\hline $\begin{array}{l}\text { Log- } \\
\text { likelihood }\end{array}$ & 85.342 & 93.296 & 94.764 & 130.483 & 147.455 & 149.411 \\
\hline
\end{tabular}

'Environment' means that regional dummies are included in the estimation of the cost frontier. 'Equity' refers to the inclusion of the bank's equity in the estimation of the cost frontier. $\mathrm{N}=747$ for the first period, $\mathrm{N}=471$ for the second period. Absolute t-statistics are displayed in parentheses, $*$, **, $* * *$ denote an estimate significantly different from zero at the $10 \%, 5 \%$ or $1 \%$ level 
Figure 1: Sberbank's dominance in the personal deposit market

Source: own calculations based on CBR Bulletin of Bank Statistics and Sberbank

\section{Sberbank share of total private deposits}

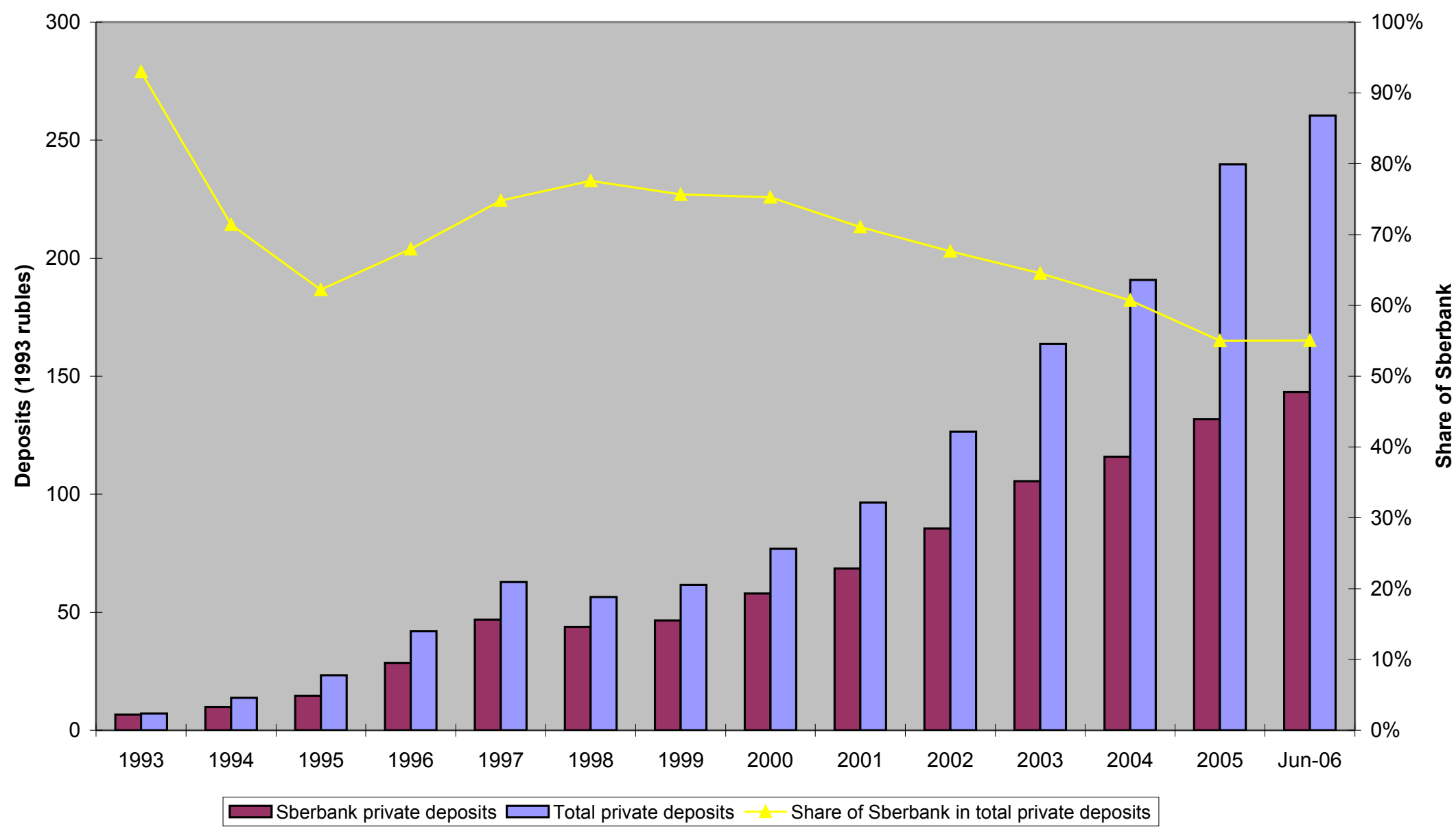




\section{ANNEX}

Table A.1: Means of key variables between private and public banks for the size-matched sample

\begin{tabular}{|c|c|c|c|c|}
\hline & \multicolumn{2}{|c|}{2002} & \multicolumn{2}{|c|}{2006} \\
\hline & Private banks & Public banks & Private banks & Public banks \\
\hline \multicolumn{5}{|l|}{ Characteristics } \\
\hline Total assets & $5,151.91$ & $7,401.68$ & $8,121.43$ & $32,322.32$ \\
\hline Total costs (production) & 203.89 & 281.03 & 388.71 & $1,108.36$ \\
\hline Total costs (intermediation) & 240.25 & 339.56 & 459.19 & $1,352.25$ \\
\hline Loans & $3,911.10$ & $4,898.84$ & $6,058.27$ & $23,751.46$ \\
\hline Deposits & $3,763.33$ & $5,315.51$ & $6,332.80$ & $25,765.57$ \\
\hline Investment assets & 325.33 & 915.25 & $1,143.52$ & $5,345.11$ \\
\hline Price of labor & 0.0083 & 0.0112 & 0.0087 & 0.0087 \\
\hline Price of physical capital & 2.4495 & 1.2885 & 2.1035 & 1.5660 \\
\hline Price of borrowed funds & 0.0105 & 0.0086 & 0.0125 & 0.0111 \\
\hline Equity/total assets & 0.2149 & 0.2313 & 0.1448 & 0.1341 \\
\hline Bad loans / loans & 0.0207 & 0.0229 & 0.0203 & 0.0107 \\
\hline \multicolumn{5}{|l|}{ Loan activities } \\
\hline Household loans / loans & 0.0495 & 0.0248 & 0.1632 & 0.1591 \\
\hline Firm loans / loans & 0.6163 & 0.6586 & 0.6431 & 0.6606 \\
\hline Government loans / loans & 0.0099 & 0.0111 & 0.0074 & 0.0189 \\
\hline Bank loans / loans & 0.3243 & 0.3055 & 0.1862 & 0.1614 \\
\hline \multicolumn{5}{|l|}{ Deposit activities } \\
\hline Household dep./ deposits & 0.1977 & 0.1204 & 0.3755 & 0.3561 \\
\hline Firm deposits / deposits & 0.5180 & 0.5858 & 0.4606 & 0.3872 \\
\hline $\begin{array}{l}\text { Government dep. } \\
\text { /deposits }\end{array}$ & 0.0359 & 0.1438 & 0.0186 & 0.1452 \\
\hline Bank dep. / deposits & 0.2484 & 0.1501 & 0.1454 & 0.1115 \\
\hline \multicolumn{5}{|l|}{ Environment } \\
\hline Moscow area & 0.6016 & 0.5882 & 0.5106 & 0.4167 \\
\hline Number of observations & 492 & 68 & 564 & 48 \\
\hline
\end{tabular}


Table A.2 Further size matched results

Panel B: Public banks defined as banks that receive a high share of interest income from the government bodies / poduction approach

\begin{tabular}{|c|c|c|c|c|}
\hline \multicolumn{5}{|c|}{ Pre generalized deposit insurance (2002) } \\
\hline $\begin{array}{l}\text { Frontier } \\
\text { characteristics }\end{array}$ & $\begin{array}{c}\text { (a) } \\
\text { environmen } \\
t\end{array}$ & $\begin{array}{c}\text { (b) } \\
\text { equity } \\
\text { and } \\
\text { environment }\end{array}$ & $\begin{array}{c}\text { (c) } \\
\text { environment } \\
\text { and } \\
\text { activities }\end{array}$ & $\begin{array}{c}\text { (d) } \\
\text { equity } \\
\text { and } \\
\text { environment } \\
\text { and activities }\end{array}$ \\
\hline Intercept & Yes & Yes & Yes & Yes \\
\hline Public banks & $\begin{array}{c}-2.934 \\
(1.40)\end{array}$ & $\begin{array}{c}-3.236^{* *} \\
(2.03)\end{array}$ & $\begin{array}{l}-0.993 \\
(0.43)\end{array}$ & $\begin{array}{c}-0.994 \\
(0.45)\end{array}$ \\
\hline Foreign banks & $\begin{array}{l}0.655 \\
(1.01)\end{array}$ & $\begin{array}{l}1.050 \\
(1.62)\end{array}$ & $\begin{array}{l}0.065 \\
(0.26)\end{array}$ & $\begin{array}{l}0.045 \\
(0.12)\end{array}$ \\
\hline Household deposits $\%$ & $\begin{array}{l}2.451 \\
(1.28)\end{array}$ & $\begin{array}{c}3.363^{* *} \\
(1.97)\end{array}$ & - & - \\
\hline Firm deposits $\%$ & $\begin{array}{l}7.025^{*} \\
(1.80)\end{array}$ & $\begin{array}{c}7.719^{* * * *} \\
(2.62)\end{array}$ & - & - \\
\hline Household loans $\%$ & $\begin{array}{l}2.563 \\
(1.47)\end{array}$ & $\begin{array}{c}3.115^{* *} \\
(2.19)\end{array}$ & - & - \\
\hline Firm loans $\%$ & $\begin{array}{l}2.356^{*} \\
(1.83)\end{array}$ & $\begin{array}{l}2.064 \\
(2.43)\end{array}$ & - & - \\
\hline Bad loans $\%$ & $\begin{array}{c}13.430^{* * *} \\
(2.14) \\
\end{array}$ & $\begin{array}{l}7.458 \\
(4.39) \\
\end{array}$ & $\begin{array}{l}6.477 \\
(1.50) \\
\end{array}$ & $\begin{array}{l}6.806 \\
(1.15) \\
\end{array}$ \\
\hline Log-likelihood & -399.040 & -397.810 & -390.961 & -390.958 \\
\hline \multicolumn{5}{|c|}{ Post generalized deposit insurance (2006) } \\
\hline Intercept & Yes & Yes & Yes & Yes \\
\hline Public banks & $\begin{array}{c}-0.386 \\
(0.93)\end{array}$ & $\begin{array}{l}-0.232 \\
(0.93)\end{array}$ & $\begin{array}{c}-3.680^{*} \\
(1.91)\end{array}$ & $\begin{array}{c}-2.779 * \\
(1.70)\end{array}$ \\
\hline Foreign banks & $\begin{array}{c}-1.221 * * * \\
(6.42)\end{array}$ & $\begin{array}{c}-0.940 * * * \\
(18.57)\end{array}$ & $\begin{array}{c}-1.943^{* *} \\
(2.41)\end{array}$ & $\begin{array}{c}-1.490^{* *} \\
(2.27)\end{array}$ \\
\hline Household deposits $\%$ & $\begin{array}{c}-0.586^{* *} \\
(2.23)\end{array}$ & $\begin{array}{l}-0.036 \\
(0.95)\end{array}$ & - & - \\
\hline Firm deposits $\%$ & $\begin{array}{l}-0.049 \\
(0.27)\end{array}$ & $\begin{array}{c}0.107 * * * \\
(2.72)\end{array}$ & - & - \\
\hline Household loans $\%$ & $\begin{array}{c}0.718^{* * *} \\
(2.81)\end{array}$ & $\begin{array}{c}0.665^{* * *} \\
(4.11)\end{array}$ & - & - \\
\hline Firm loans $\%$ & $\begin{array}{c}0.808^{* * * *} \\
(3.72)\end{array}$ & $\begin{array}{c}0.329^{* * *} \\
(5.13)\end{array}$ & - & - \\
\hline Bad loans \% & $\begin{array}{r}-0.251 \\
(0.24)\end{array}$ & $\begin{array}{c}0.881 * * * \\
(4.89) \\
\end{array}$ & $\begin{array}{c}-4.794 \\
(0.93)\end{array}$ & $\begin{array}{l}-5.458 \\
(0.77)\end{array}$ \\
\hline Log-likelihood & -365.493 & -320.609 & -350.452 & -340.378 \\
\hline
\end{tabular}


Panel C: Public banks defined as state-owned banks /intermediation approach

\begin{tabular}{|c|c|c|c|c|}
\hline \multicolumn{5}{|c|}{ Pre generalised deposit insurance (2002) } \\
\hline $\begin{array}{l}\text { Frontier } \\
\text { characteristics }\end{array}$ & $\begin{array}{c}\text { (a) } \\
\text { environmen } \\
t\end{array}$ & $\begin{array}{c}\text { (b) } \\
\text { equity } \\
\text { and } \\
\text { environment }\end{array}$ & $\begin{array}{c}\text { (c) } \\
\text { environment } \\
\text { and } \\
\text { activities }\end{array}$ & $\begin{array}{c}\text { (d) } \\
\text { equity } \\
\text { and } \\
\text { environment } \\
\text { and activities }\end{array}$ \\
\hline Intercept & Yes & Yes & Yes & Yes \\
\hline Public banks & $\begin{array}{l}-2.431 \\
(1.36)\end{array}$ & $\begin{array}{l}-3.593 \\
(1.19)\end{array}$ & $\begin{array}{r}-5.097 \\
(0.60)\end{array}$ & $\begin{array}{c}-5.466^{* *} \\
(2.06)\end{array}$ \\
\hline Foreign banks & $\begin{array}{l}-0.008 \\
(0.02)\end{array}$ & $\begin{array}{l}0.158 \\
(0.51)\end{array}$ & $\begin{array}{l}0.503 \\
(0.33)\end{array}$ & $\begin{array}{l}1.609 * \\
(1.65)\end{array}$ \\
\hline Household deposits $\%$ & $\begin{array}{l}-0.407 \\
(0.36)\end{array}$ & $\begin{array}{l}0.126 \\
(0.07)\end{array}$ & - & - \\
\hline Firm deposits $\%$ & $\begin{array}{l}0.045^{*} \\
(1.76)\end{array}$ & $\begin{array}{l}6.680 \\
(1.48)\end{array}$ & - & - \\
\hline Household loans \% & $\begin{array}{l}-1.657 \\
(0.74)\end{array}$ & $\begin{array}{l}-2.028 \\
(1.58)\end{array}$ & - & - \\
\hline Firm loans $\%$ & $\begin{array}{l}0.527 \\
(0.93)\end{array}$ & $\begin{array}{l}0.241 \\
(0.32)\end{array}$ & - & - \\
\hline Bad loans \% & $\begin{array}{c}9.552^{* *} \\
(2.10) \\
\end{array}$ & $\begin{array}{l}7.142 \\
(1.56) \\
\end{array}$ & $\begin{array}{c}17.085 \\
(0.79) \\
\end{array}$ & $\begin{array}{r}-0.539 \\
(0.14) \\
\end{array}$ \\
\hline Log-likelihood & -327.203 & -326.982 & -333.275 & -331.822 \\
\hline \multicolumn{5}{|c|}{ Post generalised deposit insurance (2006) } \\
\hline Intercept & Yes & Yes & Yes & Yes \\
\hline Public banks & $\begin{array}{l}-1.304 \\
(1.62)\end{array}$ & $\begin{array}{c}-1.393^{*} \\
(1.87)\end{array}$ & $\begin{array}{r}-1.478 \\
(0.68)\end{array}$ & $\begin{array}{r}-1.619 \\
(1.20)\end{array}$ \\
\hline Foreign banks & $\begin{array}{c}-2.031^{* *} \\
(2.03)\end{array}$ & $\begin{array}{l}-2.080^{*} \\
(1.85)\end{array}$ & $\begin{array}{r}-2.760 \\
(0.82)\end{array}$ & $\begin{array}{l}-2.668 \\
(1.25)\end{array}$ \\
\hline Household deposits $\%$ & $\begin{array}{c}-4.213^{* *} \\
(2.34)\end{array}$ & $\begin{array}{c}-4.195^{* *} \\
(2.11)\end{array}$ & - & - \\
\hline Firm deposits $\%$ & $\begin{array}{l}0.181 \\
(0.35)\end{array}$ & $\begin{array}{l}0.255 \\
(0.69)\end{array}$ & - & - \\
\hline Household loans $\%$ & $\begin{array}{c}1.548^{* *} \\
(1.99)\end{array}$ & $\begin{array}{l}1.606^{*} \\
(1.94)\end{array}$ & - & - \\
\hline Firm loans $\%$ & $\begin{array}{l}1.538^{*} \\
(1.91)\end{array}$ & $\begin{array}{c}1.450^{* *} \\
(2.19)\end{array}$ & - & - \\
\hline Bad loans \% & $\begin{array}{l}0.404 \\
(0.15)\end{array}$ & $\begin{array}{l}0.242 \\
(0.15)\end{array}$ & $\begin{array}{c}-4.044 \\
(0.63)\end{array}$ & $\begin{array}{r}-4.117 \\
(0.90)\end{array}$ \\
\hline Log-likelihood & -220.328 & -218.397 & -205.273 & -200.991 \\
\hline
\end{tabular}


Panel D: Public banks defined as banks that receive a high share of interest income from the government bodies / intermediation approach

\begin{tabular}{|c|c|c|c|c|}
\hline \multicolumn{5}{|c|}{ Pre generalised deposit insurance (2002) } \\
\hline $\begin{array}{l}\text { Frontier } \\
\text { characteristics }\end{array}$ & $\begin{array}{c}\text { (a) } \\
\text { environmen } \\
t\end{array}$ & $\begin{array}{c}\text { (b) } \\
\text { equity } \\
\text { and } \\
\text { environment }\end{array}$ & $\begin{array}{c}\text { (c) } \\
\text { environment } \\
\text { and } \\
\text { activities }\end{array}$ & $\begin{array}{c}\text { (d) } \\
\text { equity } \\
\text { and } \\
\text { environment } \\
\text { and activities }\end{array}$ \\
\hline Intercept & Yes & Yes & Yes & Yes \\
\hline Public banks & -3.323 & -4.430 & -13.875 & $-13.125^{* * *}$ \\
\hline Foreign banks & $\begin{array}{l}(1.34) \\
0.127 \\
(0.42)\end{array}$ & $\begin{array}{l}(0.66) \\
0.353 \\
(0.35)\end{array}$ & $\begin{array}{l}(1.21) \\
0.685 \\
(1.06)\end{array}$ & $\begin{array}{l}(2.57) \\
1.840^{*} \\
(1.93)\end{array}$ \\
\hline Household deposits $\%$ & $\begin{array}{l}0.276 \\
(0.23)\end{array}$ & $\begin{array}{l}0.846 \\
(0.29)\end{array}$ & - & - \\
\hline Firm deposits \% & $\begin{array}{l}4.403^{*} \\
(1.72)\end{array}$ & $\begin{array}{l}6.259 \\
(0.67)\end{array}$ & - & - \\
\hline Household loans \% & $\begin{array}{l}-1.394 \\
(0.85)\end{array}$ & $\begin{array}{l}-1.884 \\
(0.55)\end{array}$ & - & - \\
\hline Firm loans $\%$ & $\begin{array}{l}0.422 \\
(1.09)\end{array}$ & $\begin{array}{l}0.212 \\
(0.30)\end{array}$ & - & - \\
\hline Bad loans $\%$ & $\begin{array}{c}9.870 * * \\
(2.02)\end{array}$ & $\begin{array}{l}8.760 \\
(1.09) \\
\end{array}$ & $\begin{array}{l}15.098 \\
(1.54) \\
\end{array}$ & $\begin{array}{l}1.318 \\
(0.53) \\
\end{array}$ \\
\hline Log-likelihood & -331.408 & -331.208 & -334.246 & -332.787 \\
\hline \multicolumn{5}{|c|}{ Post generalized deposit insurance (2006) } \\
\hline Intercept & Yes & Yes & Yes & Yes \\
\hline Public banks & $\begin{array}{l}-1.464 \\
(0.93)\end{array}$ & $\begin{array}{l}-1.382 \\
(0.98)\end{array}$ & $\begin{array}{l}-2.555 \\
(0.54)\end{array}$ & $\begin{array}{c}-1.690 \\
(1.28)\end{array}$ \\
\hline Foreign banks & $\begin{array}{l}-1.775^{*} \\
(1.91)\end{array}$ & $\begin{array}{l}-1.832^{*} \\
(1.68)\end{array}$ & $\begin{array}{l}-2.449 \\
(0.80)\end{array}$ & $\begin{array}{l}-2.392 \\
(1.52)\end{array}$ \\
\hline Household deposits \% & $\begin{array}{c}-3.826^{* *} \\
(2.39)\end{array}$ & $\begin{array}{c}-3.849 * * \\
(2.26)\end{array}$ & - & - \\
\hline Firm deposits $\%$ & $\begin{array}{l}0.674 \\
(1.50)\end{array}$ & $\begin{array}{l}0.791 \\
(1.37)\end{array}$ & - & - \\
\hline Household loans \% & $\begin{array}{l}1.539 * \\
(1.90)\end{array}$ & $\begin{array}{l}1.622^{*} \\
(1.94)\end{array}$ & - & - \\
\hline Firm loans $\%$ & $\begin{array}{c}1.686^{* *} \\
(2.41)\end{array}$ & $\begin{array}{c}1.634^{* *} \\
(2.06)\end{array}$ & - & - \\
\hline Bad loans \% & $\begin{array}{l}0.191 \\
(0.09) \\
\end{array}$ & $\begin{array}{l}0.033 \\
(0.01) \\
\end{array}$ & $\begin{array}{c}-4.504 \\
(0.48)\end{array}$ & $\begin{array}{l}-4.400 \\
(1.21)\end{array}$ \\
\hline Log-likelihood & -223.653 & -222.113 & -205.615 & -201.543 \\
\hline
\end{tabular}




\section{PAPIERS}

\section{Laboratoire de Recherche en Gestion \& Economie (LARGE)}

D.R. $n^{\circ} 1$ "Bertrand Oligopoly with decreasing returns to scale", J. Thépot, décembre 1993

D.R. $\mathrm{n}^{\circ} 2$ "Sur quelques méthodes d'estimation directe de la structure par terme des taux d'intérêt", P. Roger - N. Rossiensky, janvier 1994

D.R. n 3 "Towards a Monopoly Theory in a Managerial Perspective", J. Thépot, mai 1993

D.R. n 4 "Bounded Rationality in Microeconomics", J. Thépot, mai 1993

D.R. n 5 "Apprentissage Théorique et Expérience Professionnelle", J. Thépot, décembre 1993

D.R. $n^{\circ} 6$ "Stratégic Consumers in a Duable-Goods Monopoly", J. Thépot, avril 1994

D.R. n 7 "Vendre ou louer ; un apport de la théorie des jeux", J. Thépot, avril 1994

D.R. n 8 "Default Risk Insurance and Incomplete Markets", Ph. Artzner - FF. Delbaen, juin 1994

D.R. n 9 "Les actions à réinvestissement optionnel du dividende", C. Marie-Jeanne - P. Roger, janvier 1995

D.R. $\mathrm{n}^{\circ} 10$ "Forme optimale des contrats d'assurance en présence de coûts administratifs pour l'assureur", S. Spaeter, février 1995

D.R. n 11 "Une procédure de codage numérique des articles", J. Jeunet, février 1995

D.R. $n^{\circ} 12$ Stabilité d'un diagnostic concurrentiel fondé sur une approche markovienne du comportement de rachat du consommateur", N. Schall, octobre 1995

D.R. n 13 "A direct proof of the coase conjecture", J. Thépot, octobre 1995

D.R. n 14 "Invitation à la stratégie", J. Thépot, décembre 1995

D.R. n 15 "Charity and economic efficiency", J. Thépot, mai 1996 
D.R. $n^{\circ} 16$ "Princing anomalies in financial markets and non linear pricing rules", P. Roger, mars 1996

D.R. n 17 "Non linéarité des coûts de l'assureur, comportement de prudence de l'assuré et contrats optimaux", S. Spaeter, avril 1996

D.R. $n^{\circ} 18$ "La valeur ajoutée d'un partage de risque et l'optimum de Pareto : une note", L. Eeckhoudt - P. Roger, juin 1996

D.R. $\mathrm{n}^{\circ} 19$ "Evaluation of Lot-Sizing Techniques : A robustess and Cost Effectiveness Analysis", J. Jeunet, mars 1996

D.R. n 20 "Entry accommodation with idle capacity", J. Thépot, septembre 1996

D.R. n 21 "Différences culturelles et satisfaction des vendeurs : Une comparaison internationale", E. Vauquois-Mathevet - J.Cl. Usunier, novembre 1996

D.R. $\mathrm{n}^{\circ} 22$ "Evaluation des obligations convertibles et options d'échange", A. Schmitt - F. Home, décembre 1996

D.R n 23 "Réduction d'un programme d'optimisation globale des coûts et diminution du temps de calcul, J. Jeunet, décembre 1996

D.R. $n^{\circ} 24$ "Incertitude, vérifiabilité et observabilité : Une relecture de la théorie de l'agence", J. Thépot, janvier 1997

D.R. $\mathrm{n}^{\circ} 25$ "Financement par augmentation de capital avec asymétrie d'information : l'apport du paiement du dividende en actions", C. Marie-Jeanne, février 1997

D.R. $\mathrm{n}^{\circ} 26$ "Paiement du dividende en actions et théorie du signal", C. Marie-Jeanne, février 1997

D.R. n 27 "Risk aversion and the bid-ask spread", L. Eeckhoudt - P. Roger, avril 1997

D.R. $n^{\circ} 28$ "De l'utilité de la contrainte d'assurance dans les modèles à un risque et à deux risques", S. Spaeter, septembre 1997

D.R. $n^{\circ} 29$ "Robustness and cost-effectiveness of lot-sizing techniques under revised demand forecasts", J. Jeunet, juillet 1997

D.R. $n^{\circ} 30$ "Efficience du marché et comparaison de produits à l'aide des méthodes d'enveloppe (Data envelopment analysis)", S. Chabi, septembre 1997

D.R. n 31 "Qualités de la main-d'œuvre et subventions à l'emploi : Approche microéconomique", J. Calaza - P. Roger, février 1998

D.R n 32 "Probabilité de défaut et spread de taux : Etude empirique du marché français", M. Merli - P. Roger, février 1998

D.R. n 33 "Confiance et Performance : La thèse de Fukuyama", 


\section{J.Cl. Usunier - P. Roger, avril 1998}

D.R. $n^{\circ} 34$ "Measuring the performance of lot-sizing techniques in uncertain environments", J. Jeunet - N. Jonard, janvier 1998

D.R. n 35 "Mobilité et décison de consommation : premiers résultas dans un cadre monopolistique", Ph. Lapp, octobre 1998

D.R. $\mathrm{n}^{\circ} 36$ "Impact du paiement du dividende en actions sur le transfert de richesse et la dilution du bénéfice par action", C. Marie-Jeanne, octobre 1998

D.R. n ${ }^{\circ} 37$ "Maximum resale-price-maintenance as Nash condition", J. Thépot, novembre 1998

D.R. $\mathrm{n}^{\circ} 38$ "Properties of bid and ask prices in the rank dependent expected utility model", P. Roger, décembre 1998

D.R. n 39 "Sur la structure par termes des spreads de défaut des obligations », Maxime Merli / Patrick Roger, septembre 1998

D.R. $\mathrm{n}^{\circ} 40$ "Le risque de défaut des obligations : un modèle de défaut temporaire de l'émetteur", Maxime Merli, octobre 1998

D.R. n ${ }^{\circ} 41$ "The Economics of Doping in Sports", Nicolas Eber / Jacques Thépot, février 1999

D.R. $\mathrm{n}^{\circ} 42$ "Solving large unconstrained multilevel lot-sizing problems using a hybrid genetic algorithm", Jully Jeunet, mars 1999

D.R n 43 "Niveau général des taux et spreads de rendement", Maxime Merli, mars 1999

D.R. n 44 "Doping in Sport and Competition Design", Nicolas Eber / Jacques Thépot, septembre 1999

D.R. n 45 "Interactions dans les canaux de distribution", Jacques Thépot, novembre 1999

D.R. n 46 "What sort of balanced scorecard for hospital", Thierry Nobre, novembre 1999

D.R. n 47 "Le contrôle de gestion dans les PME", Thierry Nobre, mars 2000

D.R. n 48 "Stock timing using genetic algorithms", Jerzy Korczak - Patrick Roger, avril 2000

D.R. n 49 "On the long run risk in stocks : A west-side story", Patrick Roger, mai 2000

D.R. $n^{\circ} 50$ "Estimation des coûts de transaction sur un marché gouverné par les ordres : Le cas des composantes du CAC40", Laurent Deville, avril 2001

D.R. n 51 "Sur une mesure d'efficience relative dans la théorie du portefeuille de Markowitz", Patrick Roger / Maxime Merli, septembre 2001 
D.R. $n^{\circ} 52 \quad$ "Impact de l'introduction du tracker Master Share CAC 40 sur la relation de parité callput", Laurent Deville, mars 2002

D.R. n 53 "Market-making, inventories and martingale pricing", Patrick Roger / Christian At / Laurent Flochel, mai 2002

D.R. $n^{\circ} 54$ "Tarification au coût complet en concurrence imparfaite", Jean-Luc Netzer / Jacques Thépot, juillet 2002

D.R. $n^{\circ} 55$ "Is time-diversification efficient for a loss averse investor ?", Patrick Roger, janvier 2003

D.R. n 56 "Dégradations de notations du leader et effets de contagion”, Maxime Merli / Alain Schatt, avril 2003

D.R. $n^{\circ} 57$ “Subjective evaluation, ambiguity and relational contracts”, Brigitte Godbillon, juillet 2003

D.R. $n^{\circ} 58$ "A View of the European Union as an Evolving Country Portfolio", Pierre-Guillaume Méon / Laurent Weill, juillet 2003

D.R. n 59 “Can Mergers in Europe Help Banks Hedge Against Macroeconomic Risk ?”, Pierre-Guillaume Méon / Laurent Weill, septembre 2003

D.R. $\mathrm{n}^{\circ} 60$ "Monetary policy in the presence of asymmetric wage indexation", Giuseppe Diana / Pierre-Guillaume Méon, juillet 2003

D.R. n 61 “Concurrence bancaire et taille des conventions de services”, Corentine Le Roy, novembre 2003

D.R. n 62 “Le petit monde du CAC 40”, Sylvie Chabi / Jérôme Maati

D.R. n 63 “Are Athletes Different ? An Experimental Study Based on the Ultimatum Game”, Nicolas Eber / Marc Willinger

D.R. $n^{\circ} 64$ "Le rôle de l'environnement réglementaire, légal et institutionnel dans la défaillance des banques : Le cas des pays émergents”, Christophe Godlewski, janvier 2004

D.R. $n^{\circ} 65$ "Etude de la cohérence des ratings de banques avec la probabilité de défaillance bancaire dans les pays émergents”, Christophe Godlewski, Mars 2004

D.R. n 66 "Le comportement des étudiants sur le marché du téléphone mobile : Inertie, captivité ou fidélité ?”, Corentine Le Roy, Mai 2004

D.R. $n^{\circ} 67$ "Insurance and Financial Hedging of Oil Pollution Risks”, André Schmitt / Sandrine Spaeter, September, 2004

D.R. $n^{\circ} 68$ "On the Backwardness in Macroeconomic Performance of European Socialist Economies", Laurent Weill, September, 2004

D.R. $\mathrm{n}^{\circ} 69$ "Majority voting with stochastic preferences : The whims of a committee are smaller than the whims of its members”, Pierre-Guillaume Méon, September, 2004 
D.R. $n^{\circ} 70$ "Modélisation de la prévision de défaillance de la banque : Une application aux banques des pays émergents”, Christophe J. Godlewski, octobre 2004

D.R. $\mathrm{n}^{\circ} 71$ "Can bankruptcy law discriminate between heterogeneous firms when information is incomplete ? The case of legal sanctions”, Régis Blazy, october 2004

D.R. $\mathrm{n}^{\circ} 72$ "La performance économique et financière des jeunes entreprises”,

Régis Blazy/Bertrand Chopard, octobre 2004

D.R. $\mathrm{n}^{\circ} 73$ “Ex Post Efficiency of bankruptcy procedures : A general normative framework”, Régis Blazy / Bertrand Chopard, novembre 2004

D.R. n 74 “Full cost pricing and organizational structure”, Jacques Thépot, décembre 2004

D.R. $n^{\circ} 75$ "Prices as strategic substitutes in the Hotelling duopoly”, Jacques Thépot, décembre 2004

D.R. n 76 "Réflexions sur l'extension récente de la statistique de prix et de production à la santé et à l’enseignement”, Damien Broussolle, mars 2005

D. R. n 77 "Gestion du risque de crédit dans la banque : Information hard, information soft et manipulation ”, Brigitte Godbillon-Camus / Christophe J. Godlewski

D.R. n 78 "Which Optimal Design For LLDAs”, Marie Pfiffelmann

D.R. n 79 “Jensen and Meckling 30 years after : A game theoretic view”, Jacques Thépot

D.R. $n^{\circ} 80$ “Organisation artistique et dépendance à l’égard des ressources”, Odile Paulus, novembre 2006

D.R. n 81 "Does collateral help mitigate adverse selection? A cross-country analysis”, Laurent Weill -Christophe J. Godlewski, novembre 2006

D.R. $\mathrm{n}^{\circ} 82$ "Why do banks ask for collateral and which ones ?”, Régis Blazy - Laurent Weill, décembre 2006

D.R. $\mathrm{n}^{\circ} 83$ "The peace of work agreement : The emergence and enforcement of a swiss labour market institution”, D. Broussolle, janvier 2006.

D.R. $\mathrm{n}^{\circ} 84$ "The new approach to international trade in services in view of services specificities : Economic and regulation issues”, D. Broussolle, septembre 2006.

D.R. $n^{\circ} 85$ "Does the consciousness of the disposition effect increase the equity premium” ?, P. Roger, juin 2007

D.R. n 86 “Les déterminants de la décision de syndication bancaire en France”, Ch. J. Godlewski

D.R. n 87 “Syndicated loans in emerging markets”, Ch. J. Godlewski / L. Weill, mars 2007

D.R. $n^{\circ} 88$ "Hawks and loves in segmented markets : A formal approach to competitive aggressiveness”, Claude d’Aspremont / R. Dos Santos Ferreira / J. Thépot, 
mai 2007

D.R. n 89 “On the optimality of the full cost pricing”, J. Thépot, février 2007

D.R. n 90 "SME's main bank choice and organizational structure : Evidence from France”, H. El Hajj Chehade / L. Vigneron, octobre 2007

D.R n 91 "How to solve St Petersburg Paradox in Rank-Dependent Models”?, M. Pfiffelmann, octobre 2007

D.R. $n^{\circ} 92$ "Full market opening in the postal services facing the social and territorial cohesion goal in France”, D. Broussolle, novembre 2007

D.R. $\mathrm{n}^{\circ}$ 2008-01 A behavioural Approach to financial puzzles, M.H. Broihanne, M. Merli, P. Roger, janvier 2008

D.R. $\mathrm{n}^{\circ}$ 2008-02 What drives the arrangement timetable of bank loan syndication ?, Ch. J. Godlewski, février 2008

D.R. $n^{\circ}$ 2008-03 Financial intermediation and macroeconomic efficiency, Y. Kuhry, L. Weill, février 2008

D.R. $\mathrm{n}^{\circ}$ 2008-04 The effects of concentration on competition and efficiency : Some evidence from the french audit market, G. Broye, L. Weill, février 2008

D.R. $\mathrm{n}^{\circ}$ 2008-05 Does financial intermediation matter for macroeconomic efficiency?, P.G. Méon, L. Weill, février 2008

D.R. n² 2008-06 Is corruption an efficient grease ?, P.G. Méon, L. Weill, février 2008

D.R. $n^{\circ}$ 2008-07 Convergence in banking efficiency across european countries, L. Weill, février 2008

D.R. $n^{\circ}$ 2008-08 Banking environment, agency costs, and loan syndication : A cross-country analysis, Ch. J. Godlewski, mars 2008

D.R. $\mathrm{n}^{\circ}$ 2008-09 Are French individual investors reluctant to realize their losses ?, Sh. Boolell-Gunesh / M.H. Broihanne / M. Merli, avril 2008

D.R. $\mathrm{n}^{\circ}$ 2008-10 Collateral and adverse selection in transition countries, Ch. J. Godlewski / L. Weill, avril 2008

D.R. $\mathrm{n}^{\circ}$ 2008-11 How many banks does it take to lend ? Empirical evidence from Europe, Ch. J. Godlewski, avril 2008.

D.R. $n^{\circ}$ 2008-12 Un portrait de l’investisseur individuel français, Sh. Boolell-Gunesh, avril 2008

D.R. n 2008-13 La déclaration de mission, une revue de la littérature, Odile Paulus, juin 2008

D.R. n²008-14 Performance et risque des entreprises appartenant à des groupes de PME, Anaïs Hamelin, juin 2008

D.R. $\mathrm{n}^{\circ}$ 2008-15 Are private banks more efficient than public banks ? Evidence from Russia, 
Alexei Karas / Koen Schoors / Laurent Weill, septembre 2008. 